\title{
Recovery from TBT pollution in English Channel environments: A problem solved?
}

*Langston, W. J., Pope, N. D., Davey, M., Langston, K.M., O' Hara, S.C.M., Gibbs, P.E. and Pascoe, P.L. Marine Biological Association, Citadel Hill, Plymouth PL1 2PB, UK. Email:wjl@mba.ac.uk

*corresponding author; email wjl@mba.ac.uk; phone +44 1752633232

\begin{abstract}
Following recognition of effects in the 1980s, tributyltin (TBT) has been monitored at sites in the English Channel to evaluate the prognosis for biota - spanning the introduction of restrictions on TBT use on small boats and the recent phase-out on the global fleet. We describe how persistence and impact of TBT in clams Scrobicularia plana has changed during this period in Southampton Water and Poole Harbour. TBT contamination (and loss) in water, sediment and clams reflects the abundance and type of vessel activity: half-times in sediment (up to $8 y$ in Poole, 33y in Southampton) are longest near commercial shipping. Recovery of clam populations - slowest in TBT-contaminated deposits - provides a useful biological measure of legislative efficacy in estuaries. On rocky shores, recovery from imposex in Nucella lapillus is evident at many sites but, near ports, is prolonged by shipping impacts, including sediment legacy, for example, in the Fal.
\end{abstract}

Keywords: TBT, recovery, Scrobicularia plana, dogwhelks, English Channel 


\section{Introduction}

The rise of the organotin (OT) 'problem', stemming from the use of tributyltin (TBT) and, to a lesser extent, triphenyltin (TPT), as biocides in antifouling (AF) preparations, has been extensively reviewed, as have the regulatory measures invoked to halt damage to vulnerable species ( $\mathrm{nb}$ oysters, stenoglossan gastropods) and coastal ecosystems (Champ and Seligman, 1996; de Mora, 1996; Bray, 2006; Arai et al., 2009). Despite the large amount of research and statutory monitoring that has been conducted (Alzieu, 2000; Hawkins et al., 2002; Waldock et al., 1999), there are still significant gaps in our knowledge of the long-term behaviour and impact of TBT - notably, the recovery of ecosystems. Indeed although improvement is ultimately expected, globally, controversy exists as to whether, in the shortterm, conditions may worsen in some parts of the world, particularly areas in Asia (Bray, 2006).

Assessing TBT pollution in sediments is particularly difficult, as it may be present in different forms, adsorbed or as paint chippings (Turner, 2010). Furthermore, unlike water - for which there is an Environmental Quality Standard (EQS) of $2 \mathrm{ng} \mathrm{L}^{-1}\left(0.8 \mathrm{ng} \mathrm{L}^{-1}\right.$ as $\left.\mathrm{Sn}\right)$ - there are no agreed quality criteria for sediments. The outlook for recovery of TBT- damaged ecosystems subjected to heavy boating/shipping activity (typified by the English Channel) therefore remains unclear, particularly in locations with persistent sedimentary sinks and is exacerbated by ambiguity over the longevity of TBT residues. Published estimates of TBT half- times in sediment are highly variable - from weeks to years depending on the nature of the benthic deposits. Persistence appears to be greatest in anoxic sediments: half-times in excess of ten years have been predicted where biological degradation is suppressed by poor mixing and lack of oxygenation (Maguire 2000). However, there is a lack of published field evidence to confirm these predictions.

Studying such aspects of recovery presents policy makers and regulators with a unique opportunity to understand the efficacy of their actions on the TBT legacy. In this context, two crucial pieces of 
legislation are likely to have influenced recuperation from TBT pollution in the Channel (with similar measures being adopted in many countries worldwide). The first of these, in 1987 in the UK (1982 in France), banned the use of TBT on vessels $<25 \mathrm{~m}$ (the leisure market), but allowed larger vessels (commercial and naval fleets) to continue usage, based on the premise that biocide leachates on large ships would be diluted, harmlessly, on the open seas. However, doubts over this assumption led to the second legislative initiative - based on IMO's proposal to remove OT-based AFs from the global fleet (beginning in 2003 with the recommendation to halt new application of OT-containing coatings, and the final adoption and ratification of the antifouling (AF) treaty in September 2008, which effectively enforced removal, or sealing, of all tin-based coatings http://www.imo.org/OurWork/Environment/AntifoulingSystems/Pages/Default.aspx). The latter was pre-empted by EU legislation in January 2008; elsewhere, sealing or removal was permissible until 2013 (to allow for the projected five-year life of a TBT coating newly applied in 2008).

UK involvement in monitoring post-legislation change in TBT status has included statutory observations (Cefas, 1998, 2000; OSPAR, 2004, 2008; Gubbins et al., 2008) and ad hoc studies, such as this. Our aims were to compare TBT trends and impacts in estuarine and coastal areas in the English Channel, including ports and harbours hosting different quantities and types of vessel (leisure craft and commercial shipping). Given the partitioning behaviour of TBT in favour of particulates (Langston and Pope, 1995) and the anticipated persistence of TBT in this phase, we have examined long-term impacts on populations of the sediment-dwelling bivalve Scrobicularia plana to determine the efficacy of regulatory measures in achieving chemical and ecological improvements. This clam typically accounts for a significant proportion of the infaunal biomass and energy-flow in unpolluted estuaries bordering the north-eastern Atlantic (Casagranda \& Boudouresque, 2005). However, as a deposit-feeder, S. plana is vulnerable to a number of sediment-associated contaminants (Ruiz et al., 1994): at heavily TBTcontaminated sites, typified by the Solent area of the English Channel, clam numbers appeared to 
decline considerably during the 1980s, as TBT concentrations peaked (Langston et al., 1990, 1994a; Langston and Burt 1991). Intuitively, clam abundance should recover as TBT levels fall, following pollution control measures. The question is: to what extent and over what timescales are improvements accomplished?

Two areas on the Channel coast of the UK were singled out to address these issues - Poole Harbour and Southampton Water. Poole Harbour was originally selected for study in the 1980 s as a possible worstcase situation with regard to TBT contamination (Langston et al., 1987). This large natural lagoon is utilised by several thousand leisure vessels (and a relatively small number of commercial ships). Because of the predominance of small craft, it was ideal for judging the effectiveness of the 1987 legislation prohibiting the use of TBT paints on boats $<25 \mathrm{~m}$. Monitoring of water, sediment, and Scrobicularia plana, has taken place here at intervals over the last two decades. Comparable monitoring has been undertaken over similar timescales in Southampton Water (hosting commercial and naval ships, in addition to yachts).

To supplement our understanding of improvements in TBT status in estuarine habitats in the Channel area we also present data on imposex in dogwhelks Nucella lapillus from rocky shores, including timeseries at previously-sampled sites in south-west England subjected to varying shipping and boating intensities. Imposex, the imposition of male characteristics (penis and vas deferens development) on females is initiated in N. lapillus by TBT concentrations as low as $0.5 \mathrm{ng} \mathrm{L}^{-1}$ (Bryan et al., 1986, 1987). Severe expression prevents egg-laying and, prior to TBT legislation, led to localised extinction of many south coast populations. TBT-induced imposex in these marine snails remains the most specific and sensitive example of the threat of endocrine disrupting chemicals (EDC) on Channel ecosystems and helped inform the development of TBT legislation. The effect of these regulatory measures on reducing the threat of TBT should, by now, have taken effect in the Channel. Indeed, surprisingly rapid (10y) 
recovery of populations (for a species lacking a planktonic larval stage) has been described at three UK locations, including SW England, by Colson and Hughes (2004). These authors suggest, from observations of genetic diversity in recolonizing individuals, that the migrant pool (crawling larvae and rafting individuals from adjacent populations) could be larger and more mobile than anticipated in organisms with such limited dispersal characteristics, thereby promoting revival of populations. To confirm the hypothesis that dog-whelk recovery is well underway and widespread in the region, we have examined trends in imposex in $N$. lapillus over the last quarter of a century at a number of sites in SW England, in the context of TBT contamination.

\section{Materials and methods}

Sampling sites: Poole and Southampton

Poole Harbour: The narrow harbour entrance and limited tidal range result in relatively restricted flushing of the primary basin (Fig. 1A). Similar features produce an even less energetic tidal regime in the secondary basins of Holes Bay and Lytchett Bay. As a consequence of the high density of leisure vessels and restricted water exchange, elevated TBT residues were encountered in various parts of the Harbour during the 1980's (Langston et al., 1987). Since boat-traffic is dominated by small craft, Poole is an ideal location to judge the effectiveness of the 1987 legislation. Water, surface sediments and, where available, sediment-dwelling clams Scrobicularia plana, were sampled for TBT on various occasions between 1987 and 2009 at sites shown in Fig. 1A. Marinas and moorings are predominantly situated along the northern shoreline, between Lytchett Bay and the Harbour mouth. In contrast, the southern shoreline is relatively undeveloped. Numbers of 'adult' bivalves $\mathrm{m}^{-2}$ were estimated by counting their characteristic siphon marks on the mud surface. Quantitative biological sampling (30 cores, totalling 0.1 $\mathrm{m}^{2} \times 10 \mathrm{~cm}$ deep, sieved at $0.5 \mathrm{~mm}$ ) was also employed on occasions as a measure of juvenile bivalve recruitment success. 


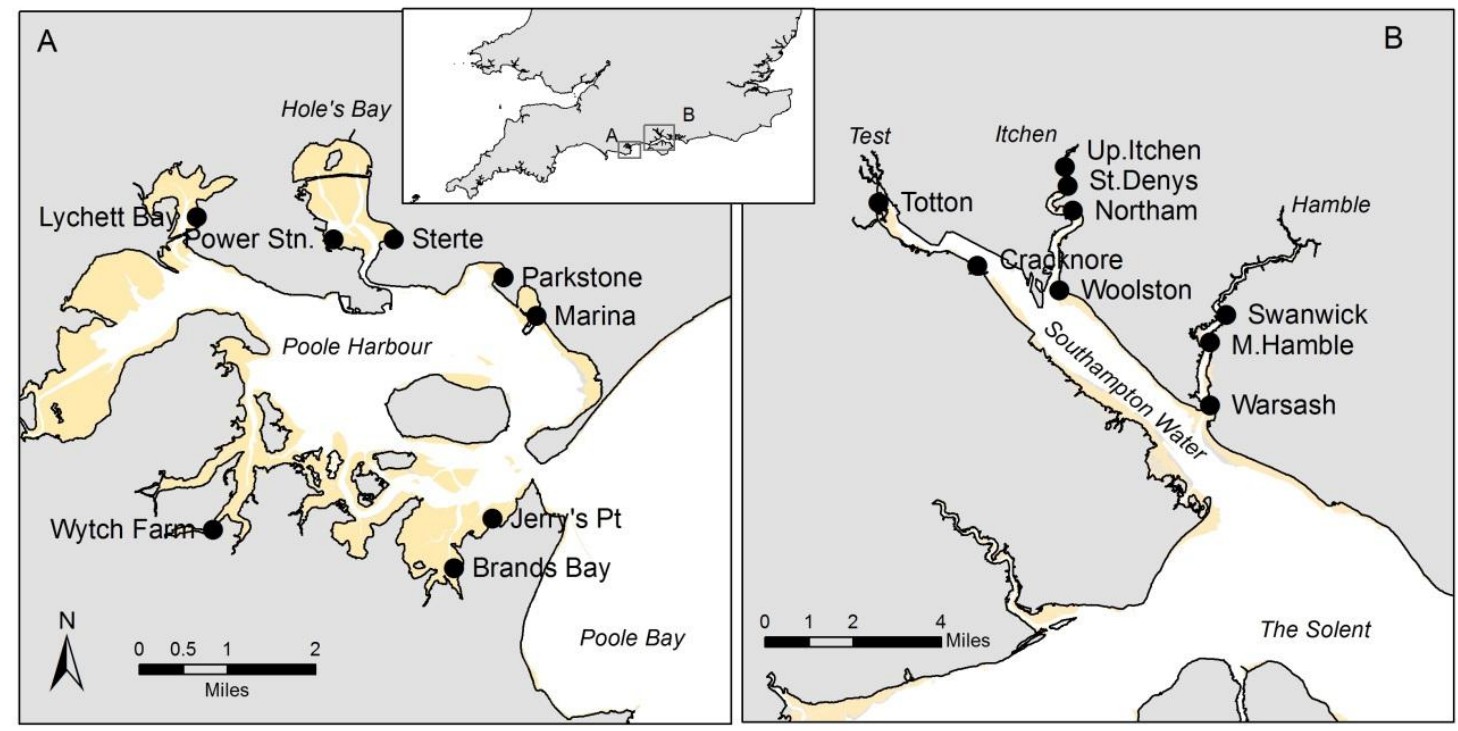

Fig. 1. Sampling sites: Poole Harbour (A) and Southampton Water (B). (abbreviations are: Power Stn. = Power Station, Jerry's Pt = Jerry's Point, Up.Itchen = Upper Itchen, M. Hamble = Mid Hamble)

Southampton Water: Southampton lies at the confluence of the Test, Hamble and Itchen Estuaries (Fig.

1B) and harbours commercial shipping and warships (mainly in the Test Estuary and Southampton

Water), together with thousands of yachts and other small craft (notably in the Hamble and, to a lesser

extent, the Itchen Estuary). TBT sampling in water, sediments and S plana from nine sites in these

estuaries (Fig. 1B) was started in 1986, prior to TBT restrictions, when the waterway became one of the

most heavily TBT-polluted areas of the UK. S. plana were sampled semi-quantitatively in timed searches,

to estimate clam densities and size cohorts. An earlier baseline study of total clam numbers in timed

searches was undertaken at some of these sites in 1978. Quantitative sampling of juvenile clams in

sediment cores, described above for Poole Harbour, was also undertaken on most occasions.

Analytical protocols for OT in Poole and Southampton samples were comparable. Water $(0.5 \mathrm{~m}$ sub-

surface) was collected in $1 \mathrm{~L}$ glass-stoppered, acid-washed glass bottles and acidified with $5 \mathrm{ml} \mathrm{L}^{-1}$ high

purity $\mathrm{HCl}$. Intertidal sediment samples were skimmed from the surface and returned to the laboratory 
on ice, sieved through $100 \mu \mathrm{m}$ polypropylene mesh with $50 \%$ seawater and allowed to settle overnight before decanting off excess water. The resulting sediment slurry was well mixed and aliquots dispensed for OT analysis, determination of water and organic content (based on the weight loss of dried sediment after ashing for $6 \mathrm{~h}$ at $400^{\circ} \mathrm{C}$ ). Scrobicularia plana, dug by hand or garden fork, were returned live to the laboratory and cleaned for 3 days ( $50 \%$ offshore seawater) prior to analysis. Shell length, wet and dry weights were recorded. OT analyses were performed on homogenised batches of six pooled S.plana.

Tributyltin (TBT) and dibutyltin (DBT) were determined by analysis of hexane-extractable forms of Sn, using graphite furnace atomic absorption (Langston et al., 1994b). Hexane extracts were shaken with $1 \mathrm{M} \mathrm{NaOH}$ to separate DBT from TBT. Reagent blanks were put through the same procedure. Detection limits for TBT and DBT in tissues and sediment, expressed as Sn on a dry weight basis, were 5-10 ng g ${ }^{-1}$ (as $\mathrm{Sn}$ ) and for seawater, $0.2 \mathrm{ng} \mathrm{L}^{-1}$ (as $\mathrm{Sn}$ ). The accuracy of analytical methods was established using reference materials and internal quality control checks, and corrected by the use of standard additions on all samples. Recovery of TBT from certified reference sediment, PACS-1, was $82 \%$, and from spiked waters $>95 \%$. Recoveries of TBT and DBT in spiked clams were $101 \%$ and $92 \%$ respectively. Intercomparison exercises for TBT analysis using other techniques (Gas Chromatography-Flame Photometric Detection/Mass Spectrometry) produce good agreement (Harino et al., 2005).

Statistical analyses of biometric and contaminant data were performed using Minitab 15. TBT concentrations have been put in context alongside the EQS (water) and other guideline values for TBT. As there are no statutory thresholds for clam tissues or sediments, comparisons are made with OSPAR (2004) generic guidelines - Ecotoxicological Assessment Criteria ( $\mathrm{EAC}_{\text {upper }}$ )- of $0.175 \mu \mathrm{g} \mathrm{g} \mathrm{g}^{-1} \mathrm{dry}$ wt for TBT in mussels (0.073 $\mu \mathrm{g} \mathrm{g}^{-1}$ as Sn) and $0.00015 \mu \mathrm{g} \mathrm{g}^{-1}$ dry weight for TBT in sediment $\left(0.00006 \mu \mathrm{g} \mathrm{g}^{-1}\right.$ as Sn). $\mathrm{EAC}_{\text {lower }}$ thresholds (below which effects are unlikely) are $0.012 \mu \mathrm{g} \mathrm{g}{ }^{-1}$ dry wt for TBT in mussels (0.005 $\mu \mathrm{g}$ $\mathrm{g}^{-1}$ as $\left.\mathrm{Sn}\right)$ and $0.00001 \mu \mathrm{g} \mathrm{g}^{-1}$ dry weight for TBT in sediment $\left(0.000004 \mu \mathrm{g}^{-1}\right.$ as $\left.\mathrm{Sn}\right)$. 
Sampling sites Nucella lapillus

The coast of southwest England has many harbours and marinas which host considerable numbers of vessels and, as a result, dogwhelks Nucella lapillus were widely impacted by TBT-induced imposex during the 1980s (Bryan et al., 1986; Gibbs et al., 1987; Langston et al., 1990). Based on repeat sampling of $N$. lapillus in 2012-13, and using the same protocols, our aim was to establish rates of re-colonisation and recovery from imposex at some of these previously-sampled sites (Fig. 2). The major ports of Falmouth and Plymouth (commercial and naval vessels and marinas) hitherto displayed some of the most severe population effects in N. lapillus and long-term surveillance positions at these locations, monitored since 1985, include Castle Drive (site 5), seaward of Falmouth Dockyard, and Renney Rocks (site 11), adjacent to Plymouth Sound. As a contrast, reference sites at Bude (Site 1) and Widemouth (Site 2) on the north Cornwall coast (much less impacted by boating or shipping activity and far removed from any major source of TBT pollution) have been scrutinised at intervals since 1985 . In addition to these principal sites, further N. lapillus populations were studied in 2012-13 at Plymouth (sites 8-10), Falmouth (sites 5-7), North Cornwall $(3,4)$, Torbay $(12,13)$ and Jersey, a reference site in mid-Channel (site 14). 


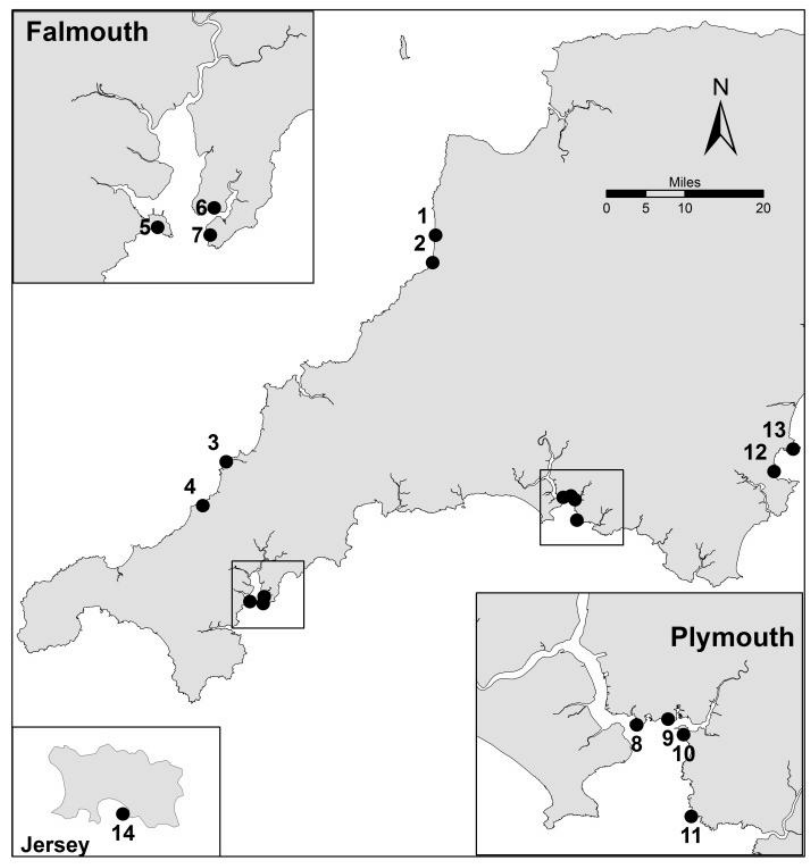

Fig. 2. Nucella lapillus sampling sites in SW England: Bude (1), Widemouth (2), Porth Joke (3), St Agnes (4), Castle Drive (5), St Mawes (6), St Anthony Head (7), Devil's Point (8), Plymouth Hoe (9), Batten (10), Renney rocks (11), Saltern Cove (12), Meadfoot (13), Jersey (14).

Dog-whelk populations were analysed for imposex using the Relative Penis Size Index (RPSI) and the Vas Deferens Sequence Index (VDSI). Adult dog-whelks ( $n=30-40$, Table 3) were examined and the length of the penis (if present) measured in both sexes to the nearest $0.1 \mathrm{~mm}$. [RPSI $=$ (mean female penis length ${ }^{3} /$ mean male penis length $\left.\left.{ }^{3}\right) \times 100\right]$. In females, the extent of any vas deferens growth was noted, and a numerical VDS stage assigned (1-6). [VDSI = mean VDS stage; used in preference to mode/median to maintain continuity with long-term observations]. A VDSI of 4 and below indicates all females are capable of breeding; a VDSI above 4 points to the presence of sterilized females and a population with a reduced breeding capacity. Several females (14 out of a total of 238 females $(5.9 \%)$ ) had a small penis but no sign of a vas deferens. As the penis was distinct and measurable, these were recorded as VDS stage 3 (a protocol followed in previous sampling and upheld to maintain consistency and practicality in scoring this complex and variable response). This particular variation in the individual expression of 
intersex has been discussed by others (Oehlmann et al., 1991; Gibbs and Bryan, 1994) and may be increasing in prevalence as exposure to TBT decreases (23\% of all females exhibiting imposex were scored in this stage 3 form in the most recent samples in this study).

An additional metric used, as given in the Water Framework Directive, was the Ecological Quality Ratio $(E Q R)=(6-V D S I) \div 6$. Tissue TBT concentrations in subsamples of dogwhelks $(n=6)$ were determined using analytical methods described above.

Size -frequency distribution was measured in the Nucella population at site 9 , Plymouth Hoe, in 2013 to compare with distributions in 1967 (pre-TBT) and in 1985 (from Drake's Island, 1km distant from the Hoe, since the population at site 9 had been eliminated at the height of the TBT threat).

\section{Results}

TBT in Poole Harbour and Southampton

Distributions and half-times (mid 1980s-2009) for TBT in various environmental compartments in Poole Harbour and Southampton were influenced by the density and type of shipping/boating activity and by the nature of the site/sample type.

\section{Poole}

Elevated TBT concentrations in water were encountered in parts of the Harbour during the 1980's, often in excess of $100 \mathrm{ng} \mathrm{L}^{-1}$ (as Sn) near marinas and moorings along the northern shoreline (Fig. 3A). In contrast, contamination levels along the undeveloped southern shoreline were mostly $<10 n \mathrm{~L}^{-1}$ (as Sn) (Fig. 3B). TBT legislation in 1987 was initially very effective at reducing concentrations: half-times (Table 1) were 1y between 1987 and 1989 (with the exception of Sterte). Between 1989 and 2009 the TBT loss was slower, especially in the less-contaminated southern area: half-times ranged from $2.2 \mathrm{y}$ at a marina site $(\mathrm{N})$ to $18.7 \mathrm{y}$ at Wytch Farm in the south (Table 1). An exponential decay pattern was to be expected; 
the rate of loss has been prolonged, most likely, by some continuing inputs from boats, together with sediment desorption (including transient pulses of TBT from dredging). However, the EQS of $2 n g$ TBT L $^{-1}$ (0.8ng L $\mathrm{L}^{-1}$ as $\mathrm{Sn}$ ) has now been achieved at most Poole sites (Fig. 3).
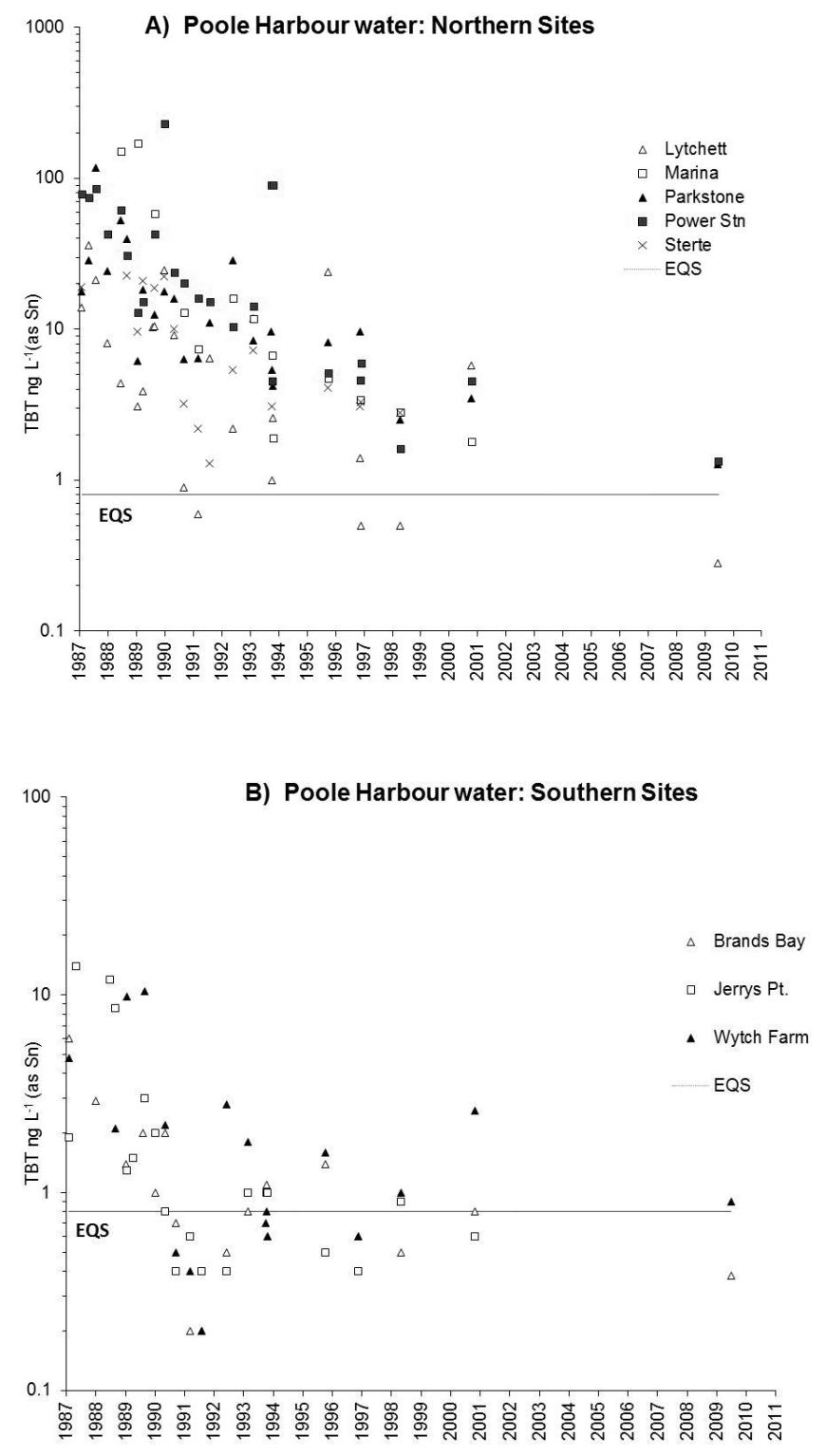

Fig. 3. TBT concentrations ( $n g \mathrm{~L}^{-1}$ as $\mathrm{Sn}$ ) in Poole Harbour waters in relation to EQS: Northern (A) and southern (B) sites - see Fig. 1A for locations. 
Table 1. TBT half-times (years) in Poole Harbour water, sediment and clams (calculated from the semilogarithmic regressions of data shown in Figs. 3-5; see Fig. 1A for locations)

\begin{tabular}{|c|c|c|c|c|c|c|c|}
\hline \multirow{2}{*}{$\begin{array}{l}\text { Site } \\
\text { (harbour area }^{\mathrm{a}} \text { ) }\end{array}$} & \multirow{2}{*}{$\begin{array}{l}\text { boat traffic } \\
\text { (mainly leisure) }\end{array}$} & \multicolumn{2}{|c|}{ Water } & \multicolumn{2}{|c|}{ Sediment } & \multicolumn{2}{|c|}{ Scrobicularia } \\
\hline & & $87-89$ & 89-09 & $87-89$ & $89-09$ & $87-89$ & $89-09$ \\
\hline Jerry's Point (S) & Low & 0.7 & 9.5 & 3.2 & 5.8 & - & - \\
\hline Brands Bay (S) & Negligible & 1.4 & 18.4 & 2.3 & 6.4 & 4.9 & 18.2 \\
\hline Wytch Farm (S) & Negligible & ns & 18.7 & 2.2 & 4.4 & 6.4 & 24.0 \\
\hline Parkstone (N) & Moderate & 1.6 & 6.1 & 6.9 & 4.2 & 3.02 & 7.44 \\
\hline Power Stn N) & Moderate & 1.2 & 3.8 & 2.4 & 4.9 & - & - \\
\hline Sterte $(\mathrm{N})$ & Moderate-high & 14.3 & 5 & 7.7 & 4.9 & 2.0 & 8.8 \\
\hline Lytchett Bay (N) & Low-moderate & 1.4 & 5.6 & ns & 4.9 & 1.57 & 15.7 \\
\hline Marina (N) & High & 0.9 & 2.2 & - & - & - & - \\
\hline
\end{tabular}

${ }^{a}$ northern (N) or southern(S) sector. ns regression not significant. $\quad$ - no sample.

TBT partitioning towards sediments in Poole Harbour resulted in spatial distributions similar to water, with severest contamination occurring in areas associated with high boating activity. TBT concentrations of $\sim 1 \mu \mathrm{g} \mathrm{g}^{-1}$ (as Sn) were not uncommon in sediment at northern sites in 1987, almost an order of magnitude higher than those in the south (Fig. 4). Subsequently, (apart from small pulses during the early 1990s, most evident at the power station site near an expanding marina), there has been consistent decline in contamination. TBT half-times in sediment were generally longer than in water in the initial two years post-ban, ranging from 2-8y (Table 1). Since 1989, half-times in sediment have been shorter than overlying water, perhaps as a result of enhanced release back into the aqueous phase, as new TBT inputs decline (Langston and Pope, 1995). Throughout the entire study period, sediment TBT concentrations were above the EAC thresholds (OSPAR, 2004), though these guideline values are extremely protective. Sediment TBT concentrations, even in the north of the harbour (Fig. 4), are now below the more relevant upper and lower Cefas Action levels for disposal at sea (1 and $0.1 \mu \mathrm{g}^{-1} \mathrm{TBT}$, respectively - equivalent to 0.4 and $0.04 \mu \mathrm{g} \mathrm{g}^{-1}$ as $\mathrm{Sn}$ ): Concentrations at or below the lower Action Level (AL1) are not considered a concern and are unlikely to influence licensing decisions on dredging whereas material with contaminant levels above the upper threshold (AL2), would be considered unsuitable, on ecological grounds, for dredging and sea disposal. 

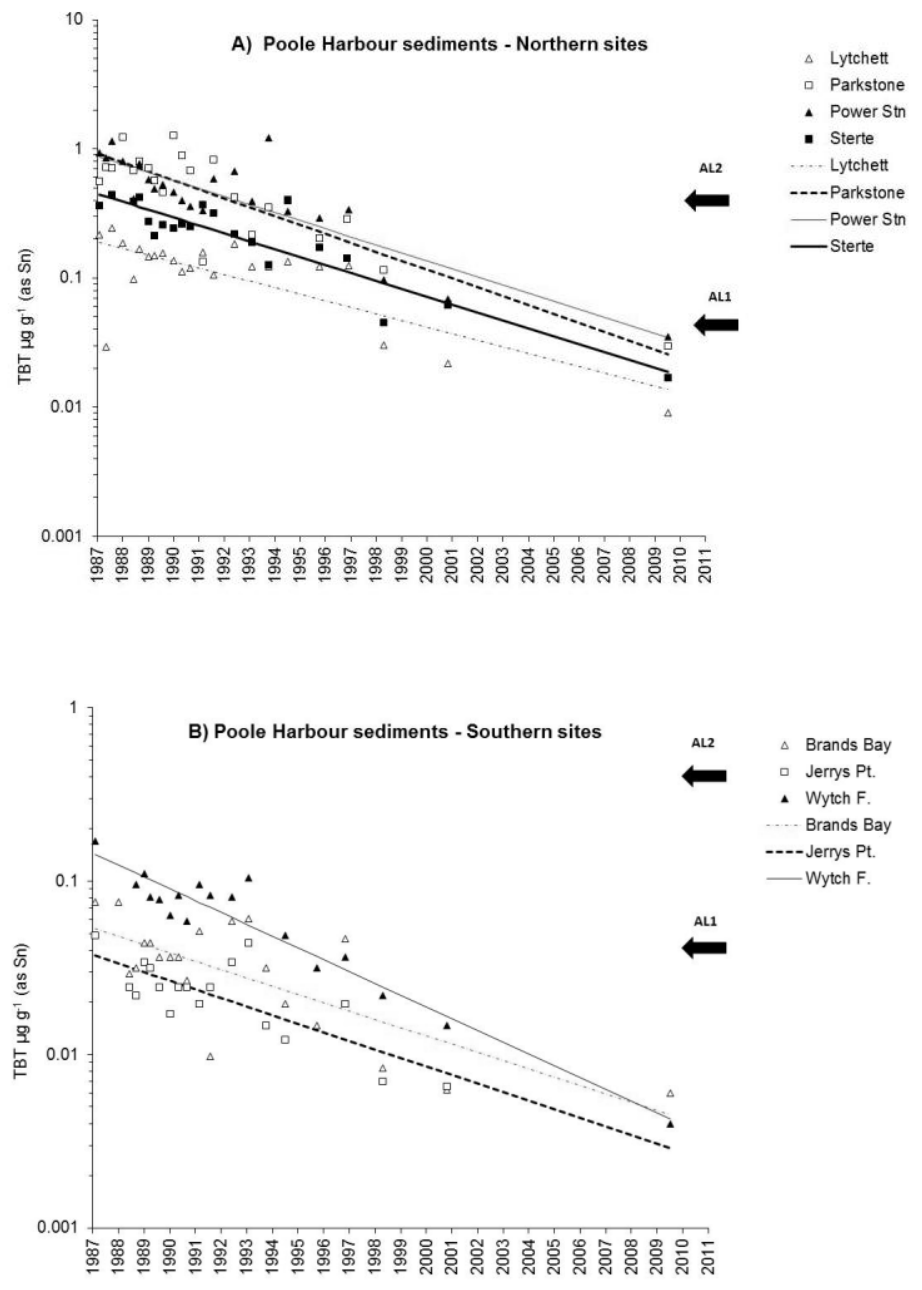

Fig. 4. TBT concentrations ( $\mu \mathrm{g} \mathrm{g}^{-1}$ as $\mathrm{Sn}$ ) in Poole Harbour sediments: northern (A) and southern (B) sites (see Fig. 1A for locations). Arrows show Cefas Action Levels (AL1 and AL2) for disposal at sea (see text for explanation). 
TBT burdens in clams S. plana in Poole Harbour (Fig. 5) reflect spatial trends in sediment and water, with concentrations varying by more than an order of magnitude between sites in the north (maximum $11.2 \mu \mathrm{g} \mathrm{g}^{-1}$, as Sn, at Parkstone in 1987) and sites in the south ( maximum $0.5 \mu \mathrm{g} \mathrm{g}^{-1}$ as Sn, Wytch Farm, 1987). Half-times for TBT in S. plana, post-1987, were variable (1.57-24 y) and were longer over the last two decades than in the two years immediately after the ban (Table 1). This pattern resembles temporal trends in TBT persistence in the environment; however, the situation in biota is complicated by the turnover of populations (5-10 year lifespan). Clams sampled in recent years have not been exposed to loadings present during the era of peak TBT contamination.

Comparisons of body burdens in S. plana with Ecotoxicological Assessment Criteria (EAC) for TBT in mussels (OSPAR, 2004) - indicate that limits were exceeded consistently at northern sites but, by 2009, were declining towards the $\mathrm{EAC}_{\text {upper }}$ (Fig. 5). At the less contaminated southern sites, concentrations of TBT in S.plana are at, or have fallen just below the $\mathrm{EAC}_{\text {upper }}$ threshold, but remain above the $\mathrm{EAC}_{\text {lower }}$. Despite retaining the expected spatial patterns of TBT contamination, reductions in body burdens have occurred in S. plana at all sites and should benefit overall clam vigour throughout the harbour. 

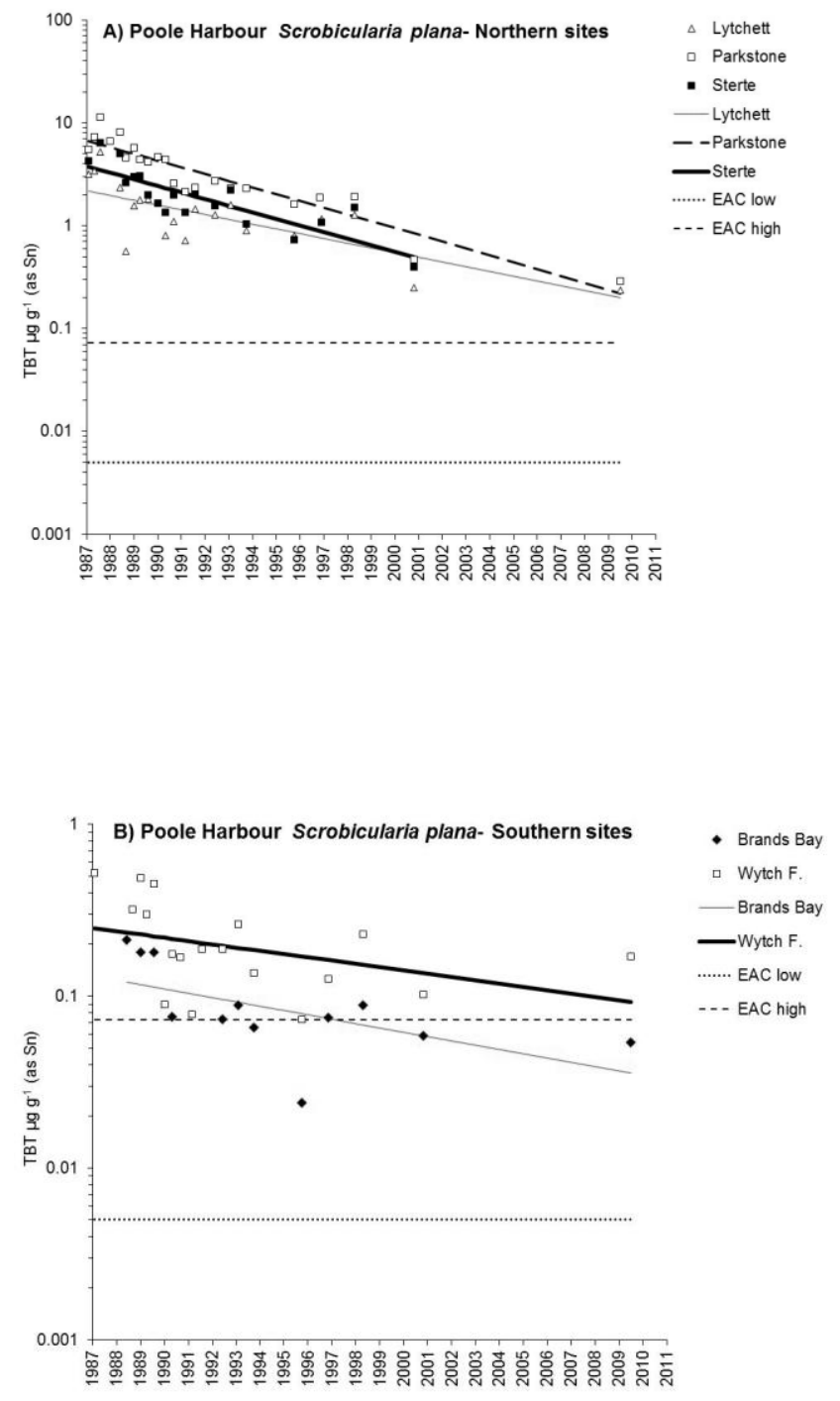

Fig. 5. Scrobicularia plana. TBT concentrations ( $\mu \mathrm{g} \mathrm{g}^{-1}$ as $\mathrm{Sn}$ ) in Poole Harbour: northern (A) and southern (B) sites -see Fig. 1A for locations.

Southampton Water

TBT concentrations $\geq 100 \mathrm{n} \mathrm{L}^{-1}$ (as Sn) were present in each of the Southampton Estuaries prior to restrictions in 1987 (Fig. 6). The Hamble Estuary is essentially one large marina housing leisure vessels along much of its length; therefore TBT half-times in water here were short immediately following TBT prohibition on small craft (mean 1.1y, 1987-1989, similar to Poole Harbour). Subsequently, rate of loss 
slowed and was even reversed for a time in the 1990s. Between 1989 and 2009 half -times ranged from 4.6-9.1 y (Table 2 and Fig. 6). Consequently, the EQS of $2 n g$ TBT L $^{-1}\left(0.8 n g L^{-1}\right.$ as Sn), initially projected for 1995 in the Hamble (Fig. 6), was only recently achieved in samples (2009). The slowing of improvement in water quality probably reflects a combination of residual TBT on small boats, sediment re-release (supplemented by dredging) and continuing influence of large vessels in Southampton Water (until 2008). Similar trends were observed in the Itchen Estuary: between 1987 and 1989, TBT half-times in water ranged from $1.4-3.2 y$. These slowed to 7.8-19.8 y between 1989 and 2009 (Table 2 and Fig. 6). Hence, initial projections -that the EQS in the Itchen would be achieved before 2000 - were not realized. TBT concentrations in water in the Test Estuary have exhibited much slower rates of loss due to the dominant effects of large vessels (up to the start of 2008 still entitled to be coated with previouslyapplied TBT antifouling). At Cracknore, in mid-estuary, TBT reduction in water immediately after the initial ban on small boats (1987-1989) was not significant - indeed concentrations increased (Table 2 and Fig. 6). Thereafter, the half-time (1989-2009) was calculated to be 10Y, with TBT concentrations remaining an order of magnitude above the EQS - enhanced, until recently, by continuing presence on shipping and inputs from repair facilities. It is likely to be a number of years before the EQS is attained in this part of the Estuary. At Totton, several km upstream of docks, TBT concentrations were substantially lower than at Cracknore, though the pattern of loss has been similar: TBT reduction in water after the initial ban (1987-1989) exhibited a half-time of 7.6 Y (Table 2 and Fig. 6), slowing subsequently (19892009) to 21.1Y. However, because of distance from sources, TBT concentrations in this lesscontaminated part of the Test are now frequently at, or below the EQS. 

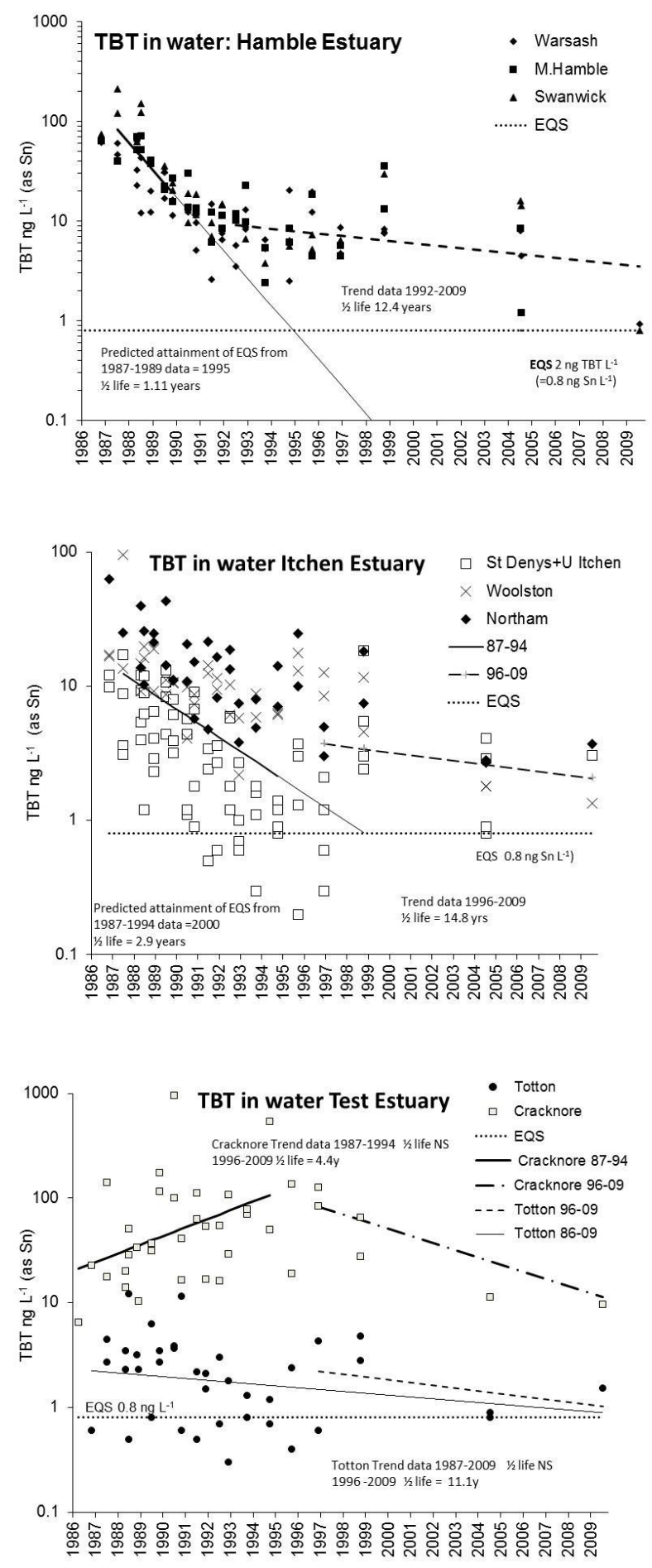

Fig. 6. TBT concentrations ( $\mathrm{ng} \mathrm{L}^{-1}$ as $\mathrm{Sn}$ ) in Hamble, Itchen and Test Estuary water, Southampton, in relation to EQS. For Hamble and Itchen, regression lines are for all sites; for Test, lines for individual sites (Cracknore and Totton) are plotted separately because of disparity (see Fig. 1B for locations). 
TBT distribution and temporal trends in Southampton sediments were similar to those in water, with severest contamination associated with high shipping and boating activity. TBT concentrations in the range $0.3->1 \mu \mathrm{g} \mathrm{g}^{-1}$ (as $\mathrm{Sn}$ ), substantially above OSPAR thresholds, and spanning Cefas Action Levels (AL), were typical in 1987 (Fig. 7). The highest value, $3.5 \mu \mathrm{g} \mathrm{g}^{-1}$ (as Sn), was recorded at Cracknore in 1995.
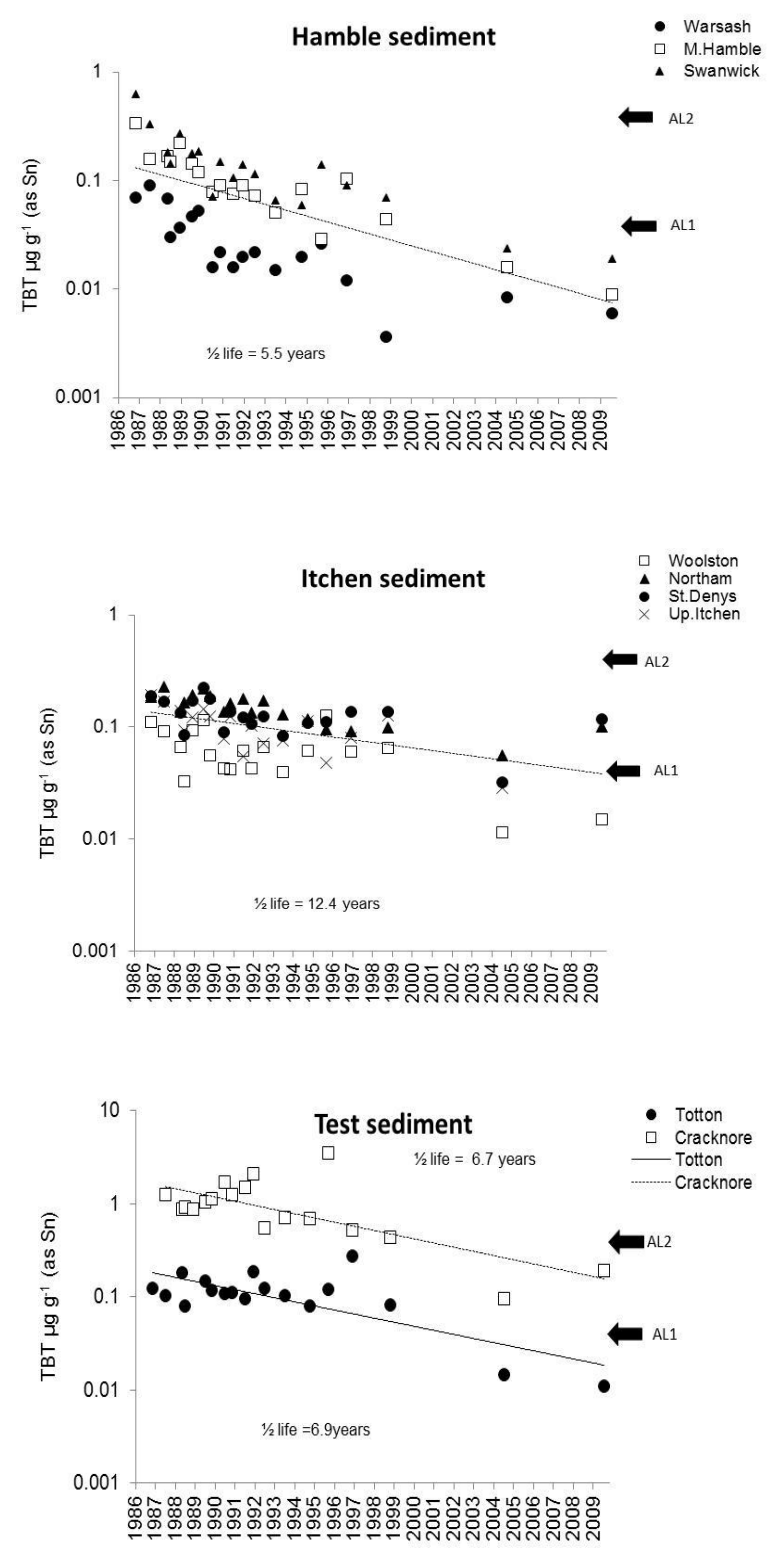

Fig. 7. TBT concentrations ( $\mu \mathrm{g} \mathrm{g}^{-1}$ as $\mathrm{Sn}$ ) in Hamble, Itchen and Test Estuary sediment, Southampton (see Fig. 1B for locations). Arrows show Cefas Action Levels (AL1 and AL2) for disposal at sea (see text). 
Half-times for TBT in sediment were generally longer than in water and, in the initial two years post-ban, ranged from 3.2y at Warsash in the mouth of the Hamble (the estuary where the ban on TBT use on small vessels was most effective), to 33y in the Test at Cracknore. Between 1987 and 1989, loss rates were insignificant at four of the Southampton sites (ns, Table 2). Since 1989, average TBT loss rates from sediment have increased in the Test ( $\left.\mathrm{T} 1 \frac{1}{2} 5.6 \mathrm{Y}\right)$-comparable to rates in the Hamble (T1/2 6.8Y). Slowest rates were those in the Itchen (T1/2 13Y). By 2009 there were no TBT concentrations above AL2: only in the Itchen and Test were levels above AL1.

TBT contamination trends in clams S. plana from Southampton estuaries (Fig. 8) were comparable to those in sediment and water, with concentrations varying between sites by more than an order of magnitude (maximum $5.15 \mu \mathrm{g} \mathrm{g}^{-1}$, as Sn, at Cracknore in the Test Estuary). TBT decline in S. plana was slow, initially - half-times ranging between not significant and 16y in 1987-1989 - with loss rates increasing between 1989-2009 (T12/2 2.5 - 6.4 y, Table 2). Half-times for TBT in clams thus tended to be shorter than in water and sediments, hastened, perhaps, by their 5-10 year lifespan.

\section{Comparisons of TBT concentrations in Southampton clams with OSPAR Ecotoxicological Assessment} Criteria (EAC) for bivalves reveal that guidelines were exceeded significantly in the past (Fig. 8). As a result of regulatory measures, concentrations of TBT in S.plana are now decreasing towards the $\mathrm{EAC}_{\text {upper }}$ threshold at many sites (with the exception of Cracknore), a reduction which would be expected to benefit the condition and survival of clams. Nevertheless, in 2009, TBT concentrations in clams at all sites were still above both the $\mathrm{EAC}_{\text {lower }}$ and $\mathrm{EAC}_{\text {upper }}$ guidelines implying a possible contribution to sublethal effects. 

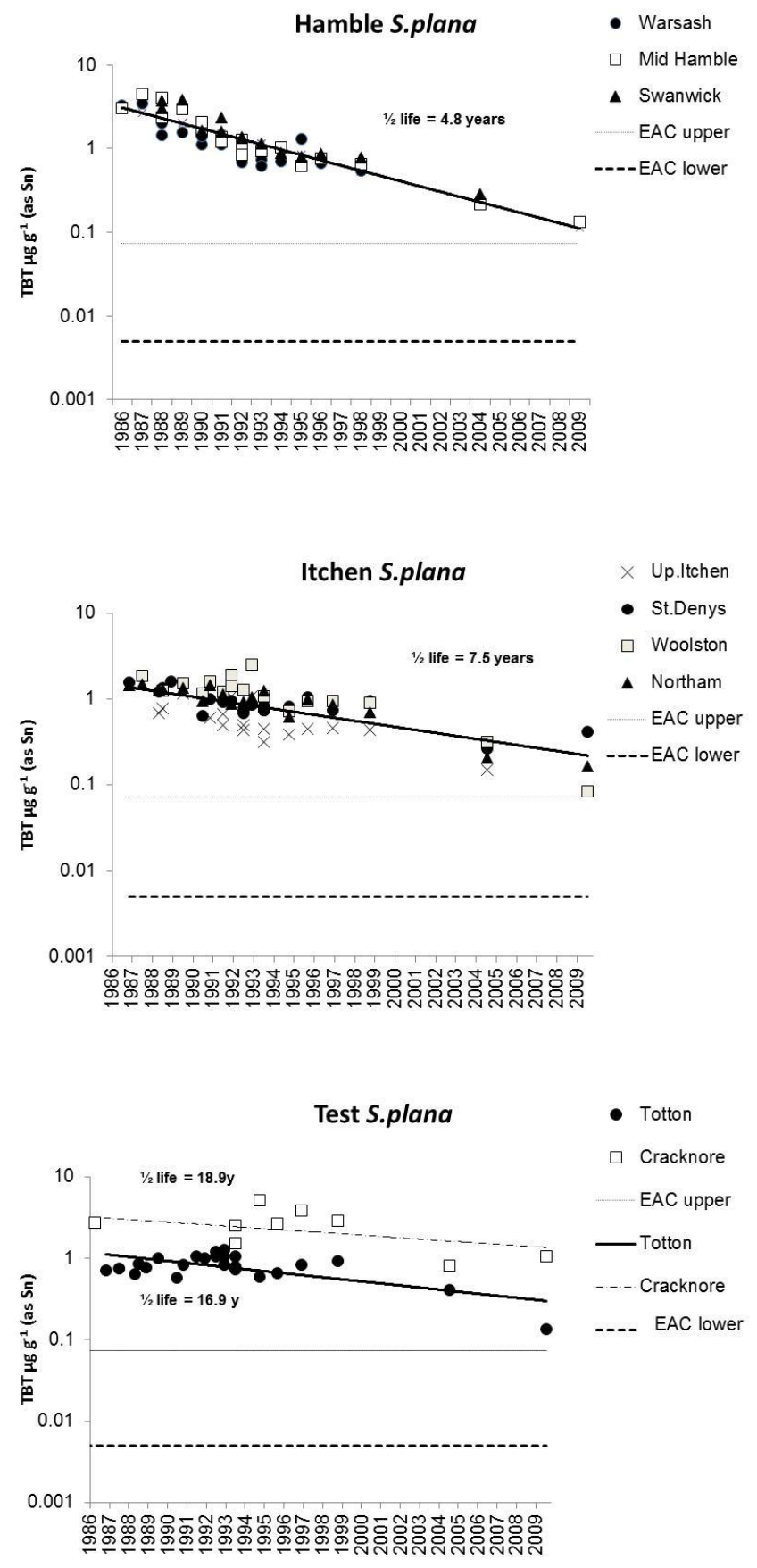

Fig. 8. Scrobicularia plana. TBT concentrations ( $\mu \mathrm{g} \mathrm{g}^{-1}$ as $\mathrm{Sn}$ ) in Hamble, Itchen and Test Estuary, Southampton (see Fig. 1B for locations). 
Table 2. TBT half-times (Years) at Southampton sites (calculated from semi-logarithmic regressions, Figs. 6-8. See Fig. 1B for locations)

\begin{tabular}{|c|c|c|c|c|c|c|c|}
\hline \multirow[b]{2}{*}{ Site (Estuary) } & \multirow[b]{2}{*}{ Boat/ship activity } & \multicolumn{2}{|c|}{ Water } & \multicolumn{2}{|c|}{ Sediment } & \multicolumn{2}{|c|}{ Scrobicularia } \\
\hline & & $87-89$ & 89-09 & $87-89$ & 89-09 & $87-89$ & 89-09 \\
\hline $\begin{array}{l}\text { Totton } \\
\text { (Test) }\end{array}$ & Upstream of port & 7.6 & 21.1 & ns & 5.6 & ns & 4.9 \\
\hline $\begin{array}{l}\text { Cracknore } \\
\text { (Test) }\end{array}$ & Commercial \& Naval & ns & 10.2 & 33 & 5.5 & ns & 6.4 \\
\hline $\begin{array}{l}\text { Swanwick } \\
\text { (Hamble) }\end{array}$ & Leisure-high & 0.8 & 4.6 & 3.9 & 6.6 & ns & 2.5 \\
\hline $\begin{array}{l}\text { Mid Hamble } \\
\text { (Hamble) }\end{array}$ & Leisure-high & 1.3 & 7.5 & 7.5 & 6.2 & 4.0 & 5.0 \\
\hline $\begin{array}{l}\text { Warsash } \\
\text { (Hamble) }\end{array}$ & Leisure-high & 1.4 & 9.1 & 3.2 & 7.5 & 2.0 & 3.4 \\
\hline $\begin{array}{l}\text { Upper Itchen } \\
\text { (Itchen) }\end{array}$ & Leisure low & ns & 19.8 & 9.7 & 10.5 & ns & 4.0 \\
\hline $\begin{array}{l}\text { St.Denys } \\
\text { (Itchen) }\end{array}$ & Leisure -moderate & 3.2 & 16.5 & ns & 19.3 & ns & 6.2 \\
\hline $\begin{array}{l}\text { Northam } \\
\text { (Itchen) }\end{array}$ & Leisure -high & 3.2 & 8.4 & ns & 14.2 & 16.1 & 4.2 \\
\hline $\begin{array}{l}\text { Woolston } \\
\text { (Itchen) }\end{array}$ & Leisure \& commercial & 1.4 & 7.8 & ns & 9.1 & 6.6 & 3.6 \\
\hline
\end{tabular}

Abundance of clams Scrobicularia plana

Poole

Our observations on clam abundance in Poole Harbour are largely qualitative rather than quantitative but suggest a link with TBT contamination, spatially and temporally. Live adult S. plana were considered absent $\left(<<1 \mathrm{~m}^{-2} ; 0\right.$ per man hr timed search in 2009$)$ at the Power Station site (Fig. 1), which was near $(\sim 100 \mathrm{~m})$ a large, recently developed marina, though the presence of empty S. plana shells in situ indicated their previous abundance. The only live clams found in Holes Bay were from a sparse $\left(\leq 1 \mathrm{~m}^{-2}\right)$ population at Sterte (Fig. 1). In the initial phase of the study these were old, large individuals, possibly the remnants of a spatfall before the peak of the TBT problem, and containing relatively high TBT 
concentrations ( $3-5 \mu \mathrm{g} \mathrm{g}^{-1}$, as Sn). In 2009 only one individual was collected $\left(<<1 \mathrm{~m}^{-2} ; 2\right.$ per man hr timed search). Lytchett Bay, like Holes Bay, is a secondary embayment but with lower levels of TBT contamination (maximum $2 \mu \mathrm{g} \mathrm{Sn} \mathrm{g^{-1 }} \mathrm{dw}$ in S. plana in 1987, see Figs. 3-5). Scrobicularia was present here at low densities throughout the early part of the study $\left(<1 \mathrm{~m}^{-2}\right)$ and dominated by old individuals. By 2009 numbers had increased as tissue burdens fell (75 per man hr timed search, TBT $0.24 \mu \mathrm{g} \mathrm{Sn} \mathrm{g}^{-1}$ ) but were patchy. Likewise the clam population at Parkstone in the main harbour was relatively low in density at the start of the study $\left(<1 \mathrm{~m}^{-2}\right)$, coinciding with body burdens of $\sim 6 \mu \mathrm{g} \mathrm{g}^{-1}$ (as Sn), but had increased in 2009 with the decline in contamination (32 per man hr search; TBT $0.29 \mu \mathrm{g} \mathrm{g}^{-1} \mathrm{as} \mathrm{Sn}$ ). In the southern sector of Poole Harbour, numbers of S. plana at Brands Bay were $\sim 1 \mathrm{~m}^{-2}$ (though patchy and, increasingly, subjected to smothering by algal mats -3 per man $\mathrm{hr}$ timed search in 2009). Densities have been consistently high, throughout, at the remote, boat-free Wytch Farm site $\left(1-10 \mathrm{~m}^{-2} ; 65\right.$ per man $\mathrm{hr}$ timed search in 2009), coinciding with low TBT tissue burdens (maximum $0.49 \mu \mathrm{g} \mathrm{g}^{-1}$ as Sn in 1989, $0.17 \mu \mathrm{g} \mathrm{g}^{-1}$ as $\mathrm{Sn}$ in 2009).

Sediment cores taken from Poole during the 1980 s occasionally contained juvenile S. plana (Langston et al., 1987) whilst in June 1992 cores from the Power Station (Holes Bay), Lytchett Bay and Parkstone revealed no evidence of juvenile S.plana settlement- suggesting that populations of S.plana may have been in decline at contaminated sites (Langston et al., 1990). Concentrations of TBT in sediment in the range $0.1-0.3 \mu \mathrm{g} \mathrm{g}^{-1}$ (equivalent to levels in the more contaminated Poole sediments) would almost certainly result in poor survival and contribute to a decline in clam numbers (Langston and Burt, 1991). Two decades later, there is still no evidence of sustained spatfall at previously-contaminated sites (no juvenile S.plana in cores from Holes Bay, Lytchett Bay, or Parkstone in June 2009) affirming the longterm deleterious legacy of TBT in Poole sediments. 


\section{Southampton}

Timed searches provided semi-quantitative estimates of clam abundance in Southampton Estuaries. Low numbers of S.plana were a feature of TBT-polluted sites during the 1980s and early 1990s when TBT concentrations were at their highest (Figs. 9-11). This decline is particularly evident when compared with baseline clam abundances from 1978 (where available).

We have shown that legislation in 1987 was particularly effective in reducing TBT concentrations in water, sediment and biota in the Hamble and Itchen Estuaries, presumably because small boats, the target of initial restrictions, predominate at these sites. Nevertheless, initial projections of rapid attainment of environmental quality targets in these estuaries were not fulfilled (Fig. 6), with delays to improvements attributable to sedimentary sinks, dredging, and inputs from commercial vessels nearby in Southampton Water.

As in Poole Harbour, decline and recovery of populations of S. plana in Southampton Estuaries has been a function of TBT contamination, coupled with persistence in different environmental compartments (Table 2). Despite slower-than-predicted losses of TBT, shortest half-times in Southampton were those in the small-boat dominated Hamble and in parts of the Itchen: evidence of clam recovery, as a result of declining TBT concentrations, is evident in both estuaries (Figs. 9 and 10).

In the Test Estuary, large gradients in TBT concentrations developed, depending on proximity to shipping. In the 1980s, for example, concentrations of $\sim 1 \mathrm{ng} \mathrm{L}^{-1}$ as $\mathrm{Sn}$ were typical in water at Totton, upstream of sources, increasing to $\sim 100 \mathrm{ng} \mathrm{I}^{-1}$ at Cracknore in mid-estuary, near docks and boatyards (Fig. 6); respective sediment TBT concentrations were $\sim 0.1 \mu \mathrm{g} \mathrm{g}^{-1}$ and $\sim 1 \mu \mathrm{g} \mathrm{g}^{-1}$, as Sn (Fig. 7). The 1987 legislation had little impact on TBT contamination at either site because of the dominant influence of large vessels in the Test and is reflected in the very slow recovery of clams at polluted Cracknore (Fig. 11). At this site, which is close to a ship repair facility and opposite the Port of Southampton, clams were 
eliminated for much of the 1980's and 1990's (they were relatively abundant here in 1978 prior to popular usage of TBT). Despite some settlement of small individuals in the 1990s, a sustainable adult population did not develop, probably due to the persistence of high levels of TBT. In 2009, however, there was a substantial population of clams (Fig. 11), coinciding with a decline in TBT concentrations (following the EU ban on TBT in 2008). It will be interesting to re-survey in future years, to establish if stable recruitment has become a fixture here.

The pattern of clam abundance at Cracknore contrasts with that at Totton, upstream of TBT sources; here, apart from a dip in clam numbers in the mid-late 1980s, the adult clam population has remained abundant, frequently exceeding 150 individuals/man hr collecting effort, and coinciding with low TBT concentrations (Fig. 11). This pattern is also reflected in juvenile clam numbers in sediment cores; in 2009, nineteen juveniles were recovered from 30 cores at Totton ( $0.01 \mu \mathrm{g} \mathrm{g}^{-1} \mathrm{TBT}$, as $\mathrm{Sn}$, in sediment), compared with a single specimen at Cracknore $\left(0.19 \mu \mathrm{g} \mathrm{g}^{-1} \mathrm{TBT}\right.$, as $\left.\mathrm{Sn}\right)$. It is possible that the more viable Totton population has acted as a nursery ground for S.plana in the Test- a source of larvae which are gradually re-colonising previously-impoverished sites downstream. 

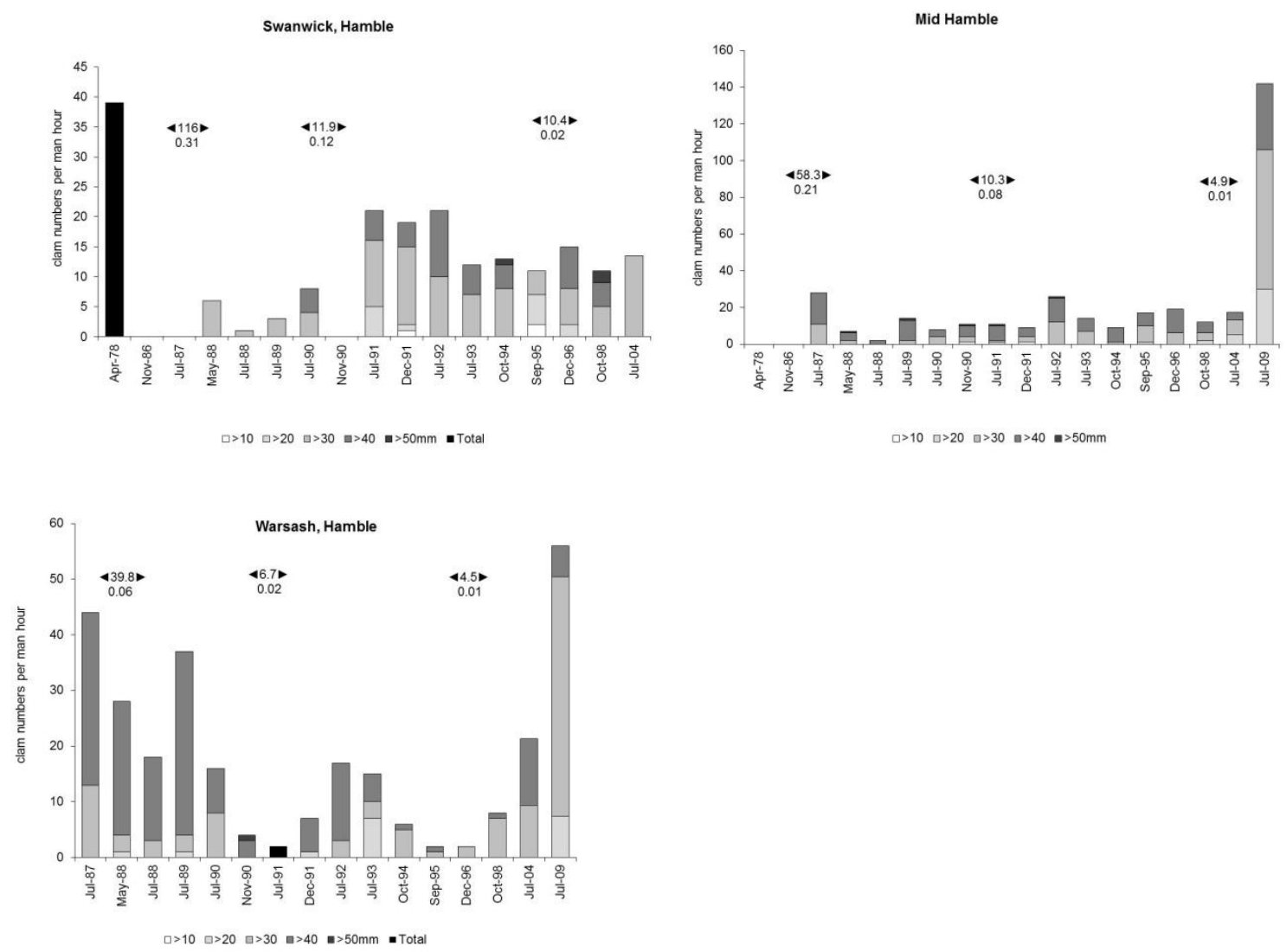

Fig. 9. Scrobicularia plana. Abundance of clams (numbers collected per man hour) at sites in the Hamble Estuary 1978-2009. Data in 1978 are total clam numbers; numbers of different sized clams (10 $\mathrm{mm}$ intervals) are indicated at other times. Upper numbers above bars are mean TBT seawater concentrations (ng L ${ }^{-1}$ as Sn) for periods 1986-1988, 1990-1992, 2000-2009 (left to right). Lower numbers are mean sediment TBT concentrations ( $\mu \mathrm{g} \mathrm{g}^{-1}$ as $\mathrm{Sn}$ ) for the same periods. 

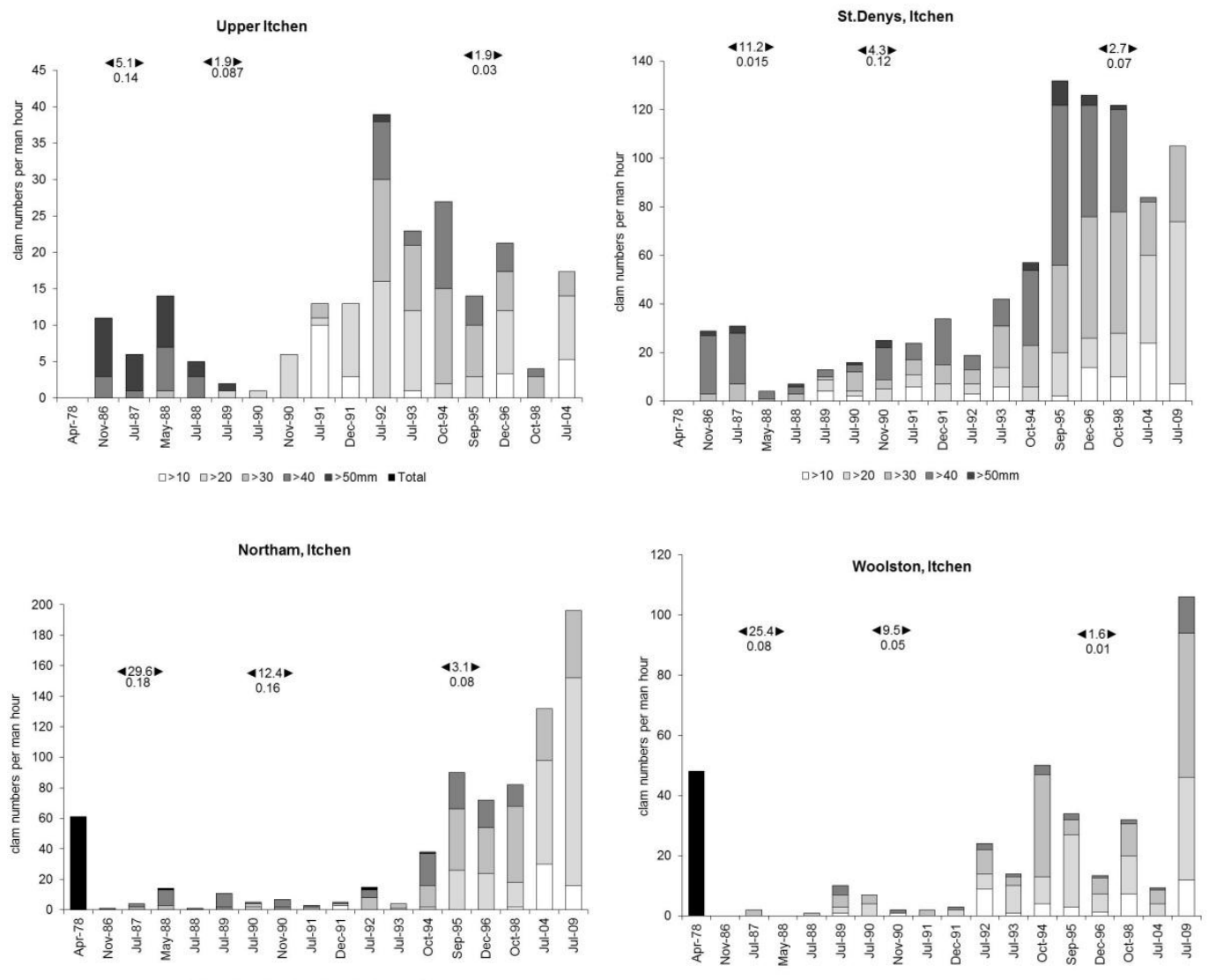

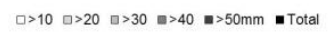

$\square>10 \square>20 \square>30 \backsim>40 \backsim>50 \mathrm{~mm} \cdot \boldsymbol{*}$ Total

Fig. 10. Scrobicularia plana. Abundance of clams (numbers collected per man hour) at sites in the Itchen Estuary 1978-2009. Data in 1978 are total clam numbers; numbers of different sized clams (10 $\mathrm{mm}$ intervals) are indicated at other times. Upper numbers above bars are mean TBT seawater concentrations (ng L ${ }^{-1}$ as Sn) for periods 1986-1988, 1990-1992, 2000-2009 (left to right). Lower numbers are mean sediment TBT concentrations ( $\mu \mathrm{g} \mathrm{g}^{-1}$ as $\mathrm{Sn}$ ) for the same periods
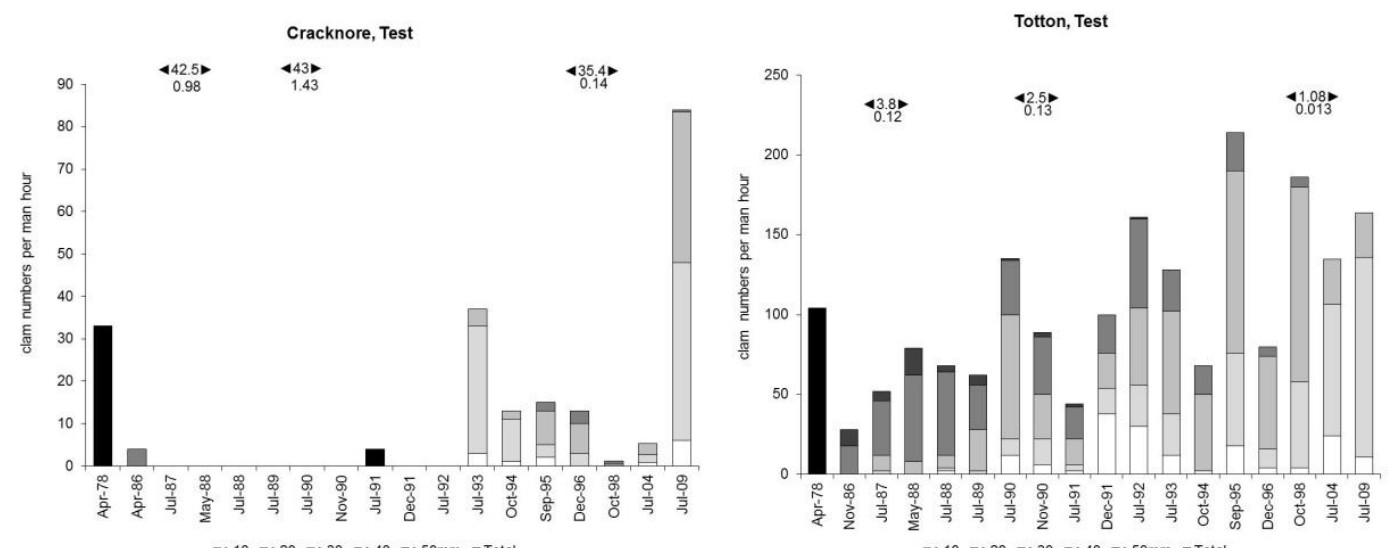

Fig. 11. Scrobicularia plana. Abundance of clams (numbers collected per man hour) at sites in the Test Estuary 1978-2009. Data in 1978 are total clam numbers; numbers of different sized clams (10 mm intervals) are indicated at other times. Upper numbers above bars are mean TBT seawater concentrations (ng L ${ }^{-1}$ as Sn) for periods 1986-1988, 1990-1992, 2000-2009 (left to right). Lower numbers are mean sediment TBT concentrations ( $\mu \mathrm{g} \mathrm{g}^{-1}$ as $\mathrm{Sn}$ ) for the same periods. 


\section{TBT-induced imposex and its application in monitoring recovery of impacted Channel sites}

Imposex indices in Nucella lapillus collected in 2012-13 at sites around SW England are presented in Table 3 and indicate low levels, especially at sites along the North Cornwall coast, Torbay and Jersey. However, enhanced VDSI (2.8) and RPSI (4.2) were still present near the port of Falmouth (sites 5-7, Fig. 2). During the TBT zenith, 25 years ago, RPS values in SW England were higher, typically 40 near harbours, with VDS stages in the range 4-6 (Gibbs et al., 1987). Even at 'clean' coastal sites (sites 1-4, Fig. 2), populations exhibited moderate imposex during the 1980 s (53-88\% at VDS stage $3 \& 4$ ) and surprisingly few females (<1\%) were without imposex. In extreme cases along the south coast, TBT contamination led to extinction of populations (e.g. Plymouth Hoe, site 9; Fig. 2). Recovery here is now almost complete, as indicated by size-frequency abundances (Fig. 12; note that in 1985 dogwhelks had been completely eliminated from the original Hoe site and data presented for that year are for nearest survivors - on Drake's Island, approximately $1 \mathrm{~km}$ offshore). Generally, populations without juveniles (such as this 1985 Drake's Island sample) signify an ageing population with little recruitment (i.e. affected by imposex). In contrast, an extensive size-frequency range (as in 1967, Fig. 12) is indicative of a breeding, sustainable population. By 2013 the Nucella population at Plymouth Hoe had become reestablished and exhibited a broad size spectrum similar to that in 1967, before widespread application of TBT anti-fouling (Fig. 12).

Recent (2012-13) levels of imposex in the southwest Channel, summarised in table 3 (along with TBT and DBT concentrations in tissues of female and male Nucella) illustrate that the proportion of females displaying imposex ranged from $0 \%$ (Widemouth) to $>75 \%$ (Falmouth). However, it is noteworthy that although several females from the three Falmouth sites were assigned a VDS stage 4, no females in any population were established as sterile, a significant improvement in condition. Imposex frequencies at Plymouth show similar improvements, with the proportion of affected females at site 9 now $<1 \%$ (Fig. 12). 

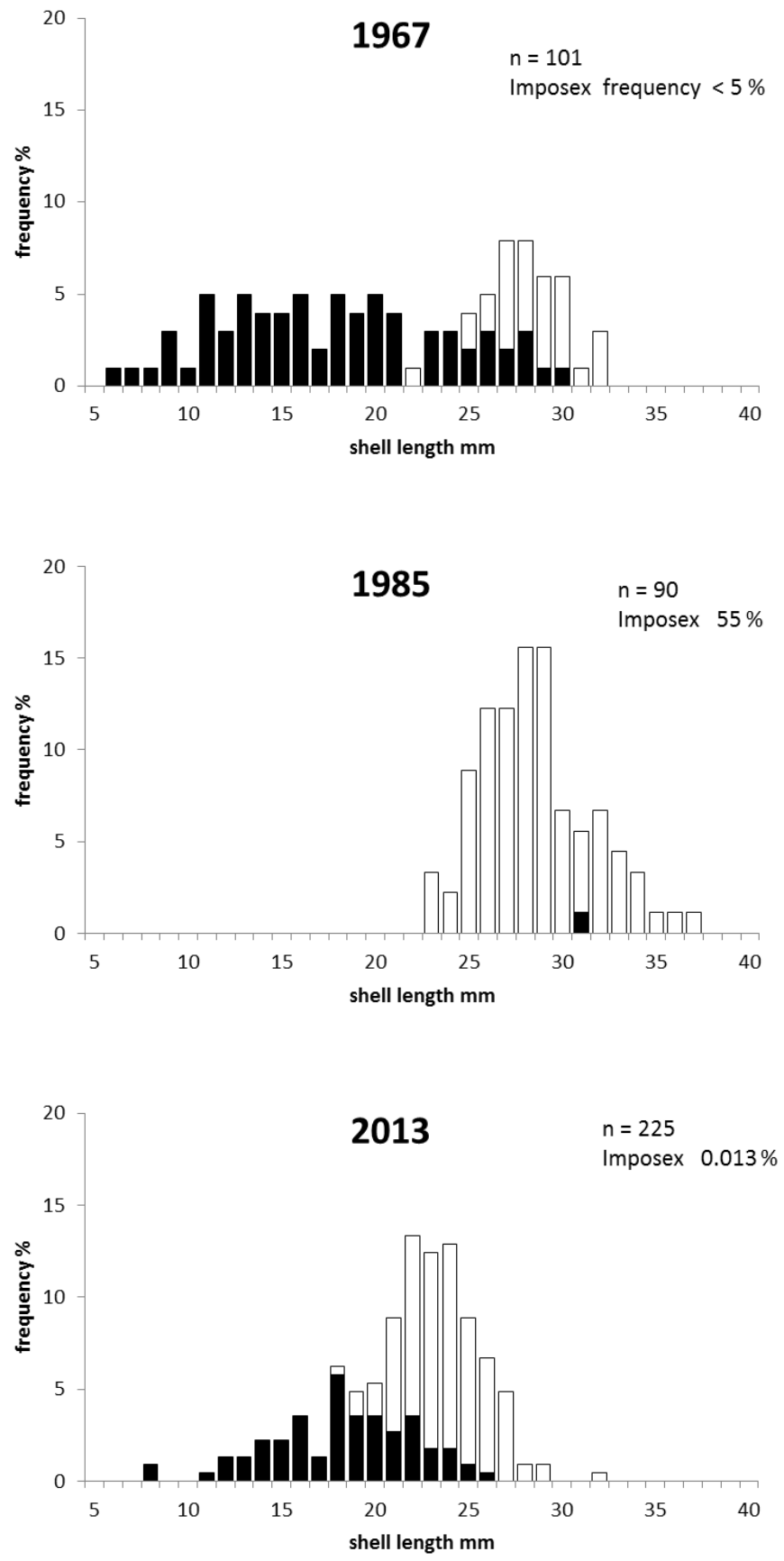

Fig. 12. Nucella lapillus. Size - frequency abundances, Plymouth Hoe (Site 9, Fig. 2). Filled bars represent individuals with no teeth on the shell margin (usually juveniles or sub-adults); unfilled bars represent individuals with dentate outer lip (usually adults). 1985 sample is from Drake's Island, offshore, due to elimination from the Hoe site. (Note: despite the presence of adults at the Drake's Island site, the absence of juveniles indicates negligible new recruitment). 
Time-series for VDSI at Castle Drive (Falmouth), Renney Rocks (near Plymouth), Bude and Widemouth confirm the overall improvements in imposex, whilst illustrating continuing spatial variation in impact and recovery (Fig. 13). Although there is now no trace of imposex at Bude, Widemouth or Renney, and improvement is evident at Castle Drive, the continuing influence of TBT from Falmouth dockyard and the legacy in Fal Estuary deposits has delayed recovery from imposex at the latter site.

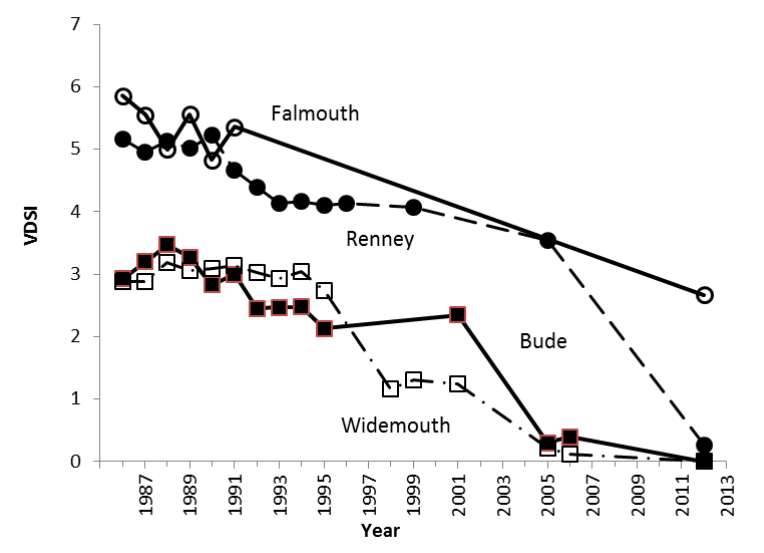

Fig. 13. Nucella lapillus. Changes in mean VDSI at four SW sites over a 25 year period. See Fig. 2 for locations

The relationship between tissue organotin levels and the VDSI expressed by adult females has been shown previously to correlate closely (Gibbs et al., 1987). Although the correlation is not as significant in recent samples, due to much lower tissue TBT concentrations and reduced imposex severity, the relationship is still evident $\left(r=0.6266, p<0.01\right.$, linear regression VDSI vs $\sum T B T+D B T$ for samples in Table 3) and enrichment in TBT continues to be detectable in Falmouth and Plymouth dogwhelks (Table 3). 
Table 3. Nucella lapillus. Imposex and organotin levels ( $\mu \mathrm{g} \mathrm{g}^{-1}$ as $\mathrm{Sn}$ ) at sites in the south west Channel Region 2012-13 (For site positions see Fig. 2).

\begin{tabular}{|c|c|c|c|c|c|c|c|c|c|c|c|c|c|c|c|c|c|c|}
\hline ID & Site & MapRef & Date & Size $\mathrm{mm}$ & No & Males & Females & RPSI & $\begin{array}{r}\text { VDSI } \\
\text { impose }\end{array}$ & EQR & TBT & DBT & $\begin{array}{l}\text { TBT+DBT } \\
\text { ale }\end{array}$ & \%ТВТ & \multicolumn{3}{|c|}{ female } & \%ТВT \\
\hline 1 & Bude & SS 201072 & $31 / 08 / 2012$ & 25.9 & 30 & 18 & 12 & 0.00 & 0 & 1 & 0.005 & 0.004 & 0.009 & 55.5 & 0.021 & 0.006 & 0.027 & 77.9 \\
\hline 2 & Widemouth & SS 195016 & $31 / 08 / 2012$ & 26.0 & 30 & 8 & 22 & 0.00 & 0 & 1 & 0.050 & 0.008 & 0.057 & 86.7 & 0.032 & 0.004 & 0.036 & 88.8 \\
\hline 3 & Porth Joke & SW 771607 & $15 / 02 / 2013$ & 27.3 & 35 & 14 & 21 & 0.00 & 0.00 & 1.00 & 0.001 & 0.002 & 0.003 & 47.8 & 0.015 & 0.002 & 0.017 & 91.1 \\
\hline 4 & St. Agnes & SW 723517 & $15 / 02 / 2013$ & 28.4 & 35 & 12 & 23 & 0.00 & 0.26 & 0.96 & 0.009 & 0.002 & 0.010 & 85.2 & 0.021 & 0.002 & 0.023 & 93.4 \\
\hline 5 & Castle Drive & SW 820320 & $07 / 07 / 2012$ & 24.9 & 35 & 26 & 9 & 2.46 & 2.67 & 0.56 & 0.027 & 0.025 & 0.052 & 51.6 & 0.031 & 0.019 & 0.050 & 61.9 \\
\hline 6 & St. Mawes & SW 849330 & $07 / 07 / 2012$ & 27.8 & 30 & 13 & 17 & 4.24 & 2.76 & 0.54 & 0.037 & 0.021 & 0.057 & 64.0 & 0.150 & 0.055 & 0.205 & 73.2 \\
\hline 7 & St Anthony Hd & SW 847316 & $07 / 07 / 2012$ & 26.9 & 30 & 10 & 20 & 0.98 & 2.65 & 0.56 & 0.028 & 0.023 & 0.051 & 55.4 & 0.012 & 0.020 & 0.032 & 37.5 \\
\hline 8 & Devils Pt & SX 463534 & $24 / 05 / 2012$ & 24.4 & 30 & 15 & 15 & 0.00 & 0.2 & 0.97 & 0.007 & 0.009 & 0.016 & 42.9 & 0.002 & 0.010 & 0.010 & 15.2 \\
\hline 9 & Plymouth Hoe & SX 479537 & $23 / 05 / 2012$ & 25.9 & 30 & 11 & 19 & 0.01 & 0.79 & 0.87 & 0.033 & 0.010 & 0.043 & 77.3 & 0.010 & 0.010 & 0.020 & 48.8 \\
\hline 10 & Batten & SX 487529 & $24 / 05 / 2012$ & 25.6 & 30 & 9 & 21 & 0.01 & 1.48 & 0.75 & 0.012 & 0.015 & 0.027 & 45.5 & 0.028 & 0.021 & 0.049 & 57.2 \\
\hline 11 & Renney & SX 491487 & $13 / 05 / 2012$ & 25.2 & 35 & 17 & 18 & 0.00 & 0.44 & 0.93 & 0.035 & 0.001 & 0.036 & 96.7 & 0.014 & 0.004 & 0.018 & 78.0 \\
\hline 12 & Saltern Cove & SX 896587 & $11 / 02 / 2013$ & 28.0 & 35 & 16 & 19 & 0.01 & 1.10 & 0.82 & 0.045 & 0.002 & 0.047 & 96.8 & 0.027 & 0.002 & 0.029 & 94.8 \\
\hline 13 & Meadfoot & SX 935633 & $11 / 02 / 2013$ & 25.6 & 35 & 13 & 22 & 0.00 & 0.00 & 1.00 & 0.014 & 0.002 & 0.015 & 90.3 & 0.031 & 0.002 & 0.032 & 95.4 \\
\hline 14 & Jersey & & $27 / 09 / 2012$ & 26.7 & 90 & 50 & 40 & 0.02 & 0.75 & 0.875 & 0.006 & 0.004 & 0.010 & 62.8 & 0.025 & 0.001 & 0.026 & 95.6 \\
\hline
\end{tabular}




\section{Discussion}

TBT pollution has declined along Channel coastlines, following legislation, but complete recovery remains a distant target in some locations. The most significant evidence of the ongoing action of OTs, including endocrine disrupting activity, has involved molluscan indicators, though a range of other invertebrate populations and communities have undoubtedly been damaged (Matthiessen, 2008). On open rocky shores around the UK, including many sites surveyed here, reduced TBT contamination has resulted in recovery of dog-whelk populations from the effects of imposex (Hawkins et al., 2002; Birchenough et al., 2002, this study); nevertheless revival has been a slow process and there are still populations of neogastropods close to ports, both in the UK and elsewhere, which remain impacted (Galante-Oliveira et al., 2006; 2009; Gibbs, 2009; Ruiz et al., 2008). Current results from the SW English Channel demonstrate this most convincingly near the port of Falmouth (where imposex is still evident in surviving populations) and in the Fal Estuary itself (where previously recorded populations are still extinct). A number of post-ban studies, including the present surveys, have thus affirmed that removal of TBT from the leisure market gave incomplete protection for the marine environment, due to continuing presence of effective concentrations near docks and maintenance facilities, offshore shipping routes and anchorages (Ten Hallers-Tjabbes et al., 2003; Rato et al., 2006). It will still be a number of years before the consequent 2008 EU legislation delivers total recovery of neogastropod populations. Hotspots remain, partly because of the persistence of TBT in sediments and the potential for resuspension, especially from dredged material.

As indicated by data from Poole and Southampton, the range of TBT sediment half-times (years decades, Tables 1 and 2 ) is a function of the scale and type of boating and shipping activity and is modified by sediment features such as organic content, oxyhydroxide coatings and redox state (degradation of TBT is slowest in anoxic conditions). Observed timescales of TBT persistence in estuarine 
muds are thus broadly consistent with projections made by Maguire (2000) and are site-specific; Incomplete assessment of TBT impact in estuaries may arise, accordingly, from a limited understanding of the localised behaviour of sediment-bound TBT (Smith et al., 2008).

In Southampton Estuaries and Poole Harbour, sediment-dwelling clams have responded successfully to TBT legislation, notably where small boats are predominant, and earlier declines in numbers have been halted and reversed, as TBT concentrations fall. Recovery of infaunal communities in response to declining TBT contamination has also been charted by Waldock et al. (1999) and Smith et al. (2008) in the Crouch Estuary, Essex, another small-boat dominated system, where biggest changes (increase in crustacean and polychaete taxa and a shift in community structure) were observed within 3 years of the 1987 regulations: a more gradual macrofaunal recovery has subsequently continued over a 20y period. Similarly, reductions in TBT concentrations in seawater brought initial rapid improvements in Crassosstrea gigas populations in France, three years after early restrictions (1982); nevertheless, continuing low-level effects were observed in oysters two decades later, attributable to longevity of sediment-bound residues (Alzieu, 2000). Comparable observations were made for mussels in the St Lawrence Seaway, Canada (St.-Jean et al., 1999). Thus, where reductions of TBT concentrations have been slow, due to the combination of persistence in sediments, and continuing inputs from the commercial fleet, there has been a corresponding delay in revival of benthic invertebrate populations, particularly molluscs. In the current study this is most evident at Cracknore, Southampton, where clams were eliminated for two decades. Recent settlement of S.plana coincides with reductions in contamination, giving rise to optimism that recovery may now be sustainable, even at port sites, as TBT concentrations begin to fall below thresholds designed to protect the environment.

Nevertheless, for port authorities, regulators and conservation agencies, the issue of TBT in sediments remains a concern and a difficult management problem, particularly where re-mobilization may be 
enhanced by dredging or general disturbance (Brack, 2002; Svavarsson et al., 2001; Santos et al., 2004). A significant programme of dredging of parts of Southampton Water during the late 1990s, to improve access to ports and marinas, coincided with a reversal in the decline of TBT levels in water in some areas, as indicated for the Hamble Estuary in Fig. 6. Throughout this period (and up to 2008) shipping in the adjacent commercial port was still entitled to use TBT antifouling and this, too, may have contributed to inputs. As a result, much of the Southampton system has continued to exhibit TBT concentrations substantially above the EQS for longer than originally projected. Only in recent years has TBT contamination begun to approach the EQS (for water) and ecotoxicological guideline values for bivalve tissues (and to a lesser extent sediment). Commercial ports remain under pressure to increase the volume and size of shipping they service and, in Europe, there are plans to meet rising demand by developing some ports as regional hubs (Marcadon, 1999). Such expansion could lead to further remobilisation of sediment-bound TBT which may be transported into neighbouring unaffected or recovering sites, including important conservation areas (Side and Jowitt, 2002; Svavarsson et al., 2001). This continues to be an issue in the planned growth of the Port of Southampton where, in 2013, approval was given to dredge a further $23 \mathrm{~m}$ tonnes of material - from the approaches to Southampton Water, upstream almost as far as Totton in the Test Estuary (a distance of $25 \mathrm{~km}$ ). The consequences of a major dredging operation (adjacent to the Solent Maritime SAC), combined with scheduled disposal of spoils at a licenced dumping ground to the SE of the Isle of Wight (close to the South Wight Maritime SAC) typify the conflicting pressures which require a co-ordinated and consistent surveillance and management approach throughout the English Channel.

The direct threat from particulates enriched with TBT is a particular concern for deposit-feeding S. plana and other infauna such as mud-snails Hinia reticulata, for which sediments are the major vector for bioaccumulation (Langston and Burt 1991; Pope, 1998). The OSPAR upper ecotoxicological sediment guideline value for TBT of $0.00015 \mu \mathrm{g} \mathrm{g}^{-1}(0.00006 \mu \mathrm{g} \mathrm{g}$-1 as $\mathrm{Sn})$ is still exceeded at many sites sampled in 
Southampton and Poole. However, this guideline may be over-precautionary. CEFAS Action Limits for dredge spoils of 0.1 and $1 \mu \mathrm{g} \mathrm{g}^{-1}\left(0.04\right.$ and $0.4 \mu \mathrm{g} \mathrm{g}^{-1}$ as $\left.\mathrm{Sn}\right)$ are more consistent with concentrations affecting abundance of sediment-dwelling fauna in the field (e.g. at Cracknore where TBT values above $1 \mu \mathrm{g} \mathrm{g}^{-1}$ as Sn were implicated in the elimination of S.plana) and with experimental observations which show that sediment TBT is acutely toxic to clams at $10 \mu \mathrm{g} \mathrm{g}^{-1}$ (as Sn) and effective at concentrations as low as $0.3 \mu \mathrm{g} \mathrm{g}^{-1}$ (Langston and Burt, 1991). Other sediment bioassays have demonstrated toxicity at this level of contamination; an LC50 for TBT of $0.16 \mu \mathrm{g} \mathrm{g}^{-1}\left(0.07 \mu \mathrm{g} \mathrm{g}^{-1}\right.$ as Sn) was determined in the polychaete Arenicola marina (Cefas, 2002b), whilst at a higher organisational level, intertidal community structure and nematode assemblages were modified in sediments spiked with 1-10 $\mu \mathrm{g} \mathrm{g}^{-1} \mathrm{TBT}(0.4-4 \mu \mathrm{g}$ $\mathrm{g}^{-1}$ as $\mathrm{Sn}$ ) and in contaminated dredge spoils (Matthiessen \& Thain, 1989; Cefas, 2002a).

The mode of action of TBT impact in S. plana remains to be discovered. In contrast to TBT-induced imposex in neogastropods, which involves imposition of male sexual characteristics on females (Bryan et al., 1986; Ruiz et al., 2008; Galante-Oliveira, et al., 2009), there are no analogous reproductive structures (penis, vas deferens) in S.plana and therefore no comparable indices of masculinisation. However, analysis of sex ratios in Poole and Southampton clams in 2009 indicated deviation from the expected ratio of unity present in 'normal' populations (Langston et al., 2007). At sites in Poole and Southampton where TBT concentrations in sediments were highest there was a significant bias towards males (2:1, $p<0.05$, Fischer Exact test), compared with the Channel average of 1:1 (Fig. 14). Influence of TBT on reproductive development in S. plana is therefore a possibility; masculinisation and reduced larval production were similarly thought to have accompanied TBT-related decline in UK native oysters Ostrea edulis (Thain and Waldock, 1986). Furthermore, exposure of S. plana to (xeno)oestrogens (17ß oestradiol, nonylphenol) can induce intersex (ovotestis) in males, implying that this species is susceptible to endocrine-disrupting chemicals, albeit that the mechanisms are unknown and may not involve the conventional receptors and steroid pathways associated with endocrine disruption in vertebrates 
(Langston et al., 2007; Pope et al., Rotchell et al., this volume). Identification of the severity and mode of action of such chemicals, in ecologically-important indicators such as S. plana, are clearly pertinent goals to improve the evaluation and management of future contaminant threats to the Channel environment.

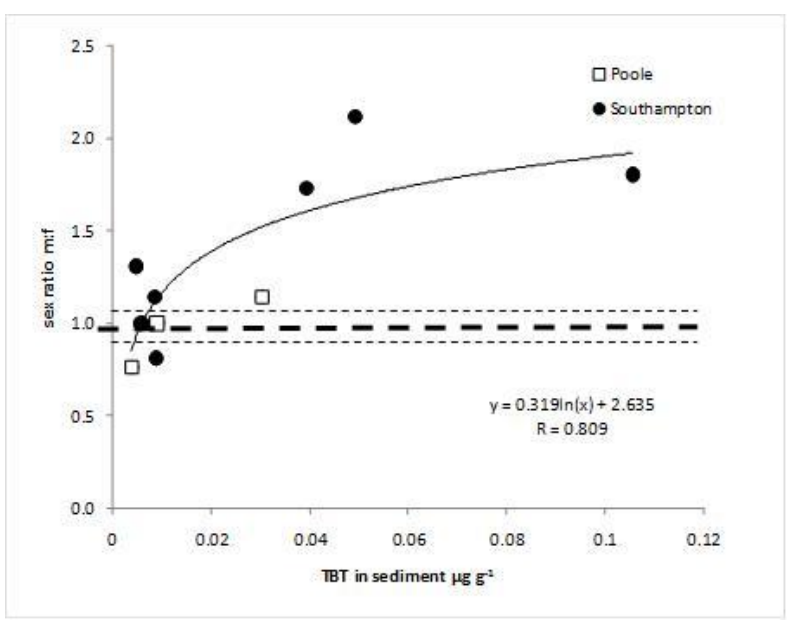

Fig. 14. Scrobicularia plana. Relationship between sex ratio and TBT content of sediment, Poole and Southampton, July 2009. Dashed line is mean ( \pm SE) sex ratio (0.998:1, male:female) for English Channel (2009-2012, $\mathrm{n}=107$ sites).

\section{Conclusions}

Legislation in 1987 prohibiting the use of organotin antifouling on boats $<25 \mathrm{~m}$ (mainly leisure craft), led to rapid chemical and ecological improvement where such vessels were dominant, as indicated by the trends and relatively short half-times for TBT in water, sediment, and clams from Poole Harbour. TBT concentrations here were initially highest at sites closest to shipping channels, marinas and moorings situated predominantly along the northern shoreline. More remote sites in the south of Poole Harbour were less impacted. Rates of TBT loss, expressed as half-times were, however, similar across all sites. In Southampton Estuaries, the 1987 TBT regulation was successful in the Hamble and Itchen (primarily leisure vessels), though in the Test (dominated by the commercial fleet, ferries and naval ships), chemical and biological recovery has been slower and the original assumption that, as these larger 
vessels spend most of their time at sea, TBT concentrations would be diluted sufficiently to prevent deleterious effects, was not upheld. Where such vessels are berthed and maintained, as in the Port of Southampton, TBT half-times have been prolonged throughout much of the 1980s, 1990s and early years of this century, delaying recovery of impacted populations of molluscs such as $S$ plana. Similar evidence from surveillance programmes around the world convinced IMO to recommend phasing out organotin antifouling compounds. These restrictions, effective in the EU in 2008, and throughout much of the world in 2013, are now starting to reap benefits in Channel ecosystems as TBT concentrations in most milieu are progressing towards thresholds designed to protect the environment. In 2009, TBT concentrations were extensively at, or below, the EQS for water (and some assessment criteria for sediment and bivalve tissues), with the exception of sites close to docks and maintenance facilities. This pattern of TBT improvement is reflected in recolonisation trends in clams. Future progress towards recovery from TBT pollution at estuarine sites is clearly dependent on factors such as the nature and severity of (historical) inputs and the stability/remobilisation of sediment-bound TBT, including dredging and disposal operations.

Recovery of rocky-shore dogwhelks from TBT-induced imposex is also subject to local influences. Though re-colonisation (and colonisation of 'new' sites; see Bray et al., 2012 ) is evident at many coastal locations, populations of $N$. lapillus remain vulnerable where there is a legacy of TBT, including availability for release from benthic deposits, as in the Fal Estuary.

Regulatory strategies have clearly been successful in stemming the TBT threat (albeit over protracted timescales). Nevertheless, the welfare of benthic mollusc populations in the Channel Region remains linked to TBT sediment loadings and availability, a quarter of a century after restrictions were first introduced. Hopefully, these findings will provide guidance in directing future surveillance strategy and policy development. 


\section{Acknowledgements}

This work was part-funded by the European Regional Development Fund in the framework of the INTERREG IVA France (Channel) - England programme ('DIESE' and ' $3 C^{\prime}$ cluster projects). Thanks are due to the reviewers for their constructive suggestions

\section{References}

Alzieu, C. (2000). Impact of tributyltin on marine invertebrates. Ecotoxicology. 9:71-76.

Arai, T., Harino, H., Ohji, M., and Langston, W.J. (Eds.) (2009). Ecotoxicology of Antifouling Biocides; Springer, Japan. 437pp. ISBN: 978-4-431-85708-2.

Birchenough, A.C., Evans, S.M., Moss, C. et al. (2002). Re-colonisation and recovery of populations of dogwhelks Nucella lapillus (L.) on shores formerly subject to severe TBT contamination. Mar Pollut Bull 44:652-659.

Brack, K. (2002) Organotin compounds in sediments from the Gota Alv estuary. Water, Air and Soil Pollution. 135: 131-140.

Bray, S. (2006). Tributyltin pollution on a global scale. An overview of relevant and recent research: impacts and issues. Langston, W.J. (Ed).Report to WWF UK. Godalming, Surrey, Contract No. FND053998 $47 p p+$ App.

Bray, S., McVean, E.C., Nelson, A. et al. (2012). The regional recovery of Nucella lapillus populations from marine pollution, facilitated by man-made structures. J. Mar. Biol. Assoc.UK, 92, 1585-1594. doi:10.1017/S0025315411001317. Bryan, G.W., Gibbs, P.E., Hummerstone, L.G. et al. (1986). The decline of the gastropod Nucella lapillus around south west England: Evidence for the effect of tributyltin from antifouling paints. J Mar Biol Ass UK 66: 611-640. 
Bryan, G.W., Gibbs, P.E., Burt, G.R. et al. (1987). The effects of tributyltin (TBT) accumulation on adult dog-whelks, Nucella lapillus: long-term field and laboratory experiments. J Mar Biol Ass UK 67: 525-544. Casagranda, C. and Boudouresque, C.F. (2005). Abundance, population structure and production of Scrobicularia plana and Abra tenuis (Bivalvia: Scrobicularidae) in a Mediterranean Brackish Lagoon, Lake Ichkeul, Tunisia. Int Rev Hydrobiol 90: 376-391.

Colson, I. and Hughes, R.N. (2004). Rapid recovery of genetic diversity of dogwhelk (Nucella lapillus) populations after local extinction and recolonisation contradicts predictions from life-history characteristics. Mol Ecol 13:2223-2233

Cefas (1998). Towards 2000: Marine Monitoring in the 1990s. The 5th report of the UK MPMMG. 48pp. Cefas (2000). Monitoring and surveillance of non-radioactive contaminants in the aquatic environment and activities regulating the disposal of wastes at sea, 1997. Science Series, Aquatic Environment Monitoring Report No. 52: 92pp.

Cefas (2002a). The fate of TBT in spoil and feasibility of remediation to eliminate environmental impact. Final Report to DEFRA. A0232.

Cefas (2002b). Development and Application of a Chronic Sediment Bioassay. Final Report to DEFRA. CW0832.

Cefas (2005). Monitoring of the quality of the aquatic environment 2002-2003. Aquatic Environment Monitoring Report, 57, 64pp.

Champ, M.A. and Seligman, P.F., (editors), (1996) Organotin. Environmental fate and effects. Chapman and Hall, London, 623pp. ISBN: 0-412-58240-6.

de Mora, S.J. (editor) (1996). Tributyltin: case study of an environmental contaminant. Cambridge University Press, Cambridge, 301pp. ISBN-13: 9780521105125.

Galante-Oliveira, S., Langston, W.J., Burt, G.R., et al.. (2006). Imposex and organotin body burden in the dog-whelk (Nucella lapillus L.) along the Portuguese coast. Applied Organometallic Chemistry, 20: 1-4. 
Galante-Oliveira, S., Oliveira, I., Jonkers, N., et al. (2009). Imposex levels and tributyltin pollution in Ria de Aveiro (NW Portugal) between 1997 and 2007: evaluation of legislation effectiveness. J. Environ. Monit., 2009, 11: $1405-1411$.

Gibbs, P.E. (2009). Long-term tributyltin (TBT)-induced sterilization of neogastropods: persistence of effects in Ocenebra erinacea over 20 years in the vicinity of Falmouth (Cornwall, UK). J Mar Biol Ass UK, 89(1): 135-138.

Gibbs, P.E. and Bryan, G.W. (1994). Biomonitoring of Tributyltin (TBT) pollution using the imposex response of neogastropod molluscs. In: Kramer, K.J.M. (Ed.) Biomonitoring of coastal waters and estuaries. CRC Press: Boca Raton. ISBN 0-8493-4895-1. pp. 205-226

Gibbs, P.E., Bryan, G.W., Pascoe, P.L. and Burt, G.R. (1987). The use of the dog-whelk, Nucella lapillus, as an indicator of tributyltin (TBT) contamination. J Mar Biol Ass UK, 67: 507-523.

Gubbins, M. J., Grewar, G., Harding, M. and Davies, I. M. (2008). SOTEAG rocky shore monitoring programme. TBT contamination in Sullom Voe, Shetland. 2007 dogwhelk survey. Fisheries Research Services Contract Report 05/08: 25pp.

Harino, H., O'Hara, S.C.M., Burt, G.R., et al. (2005). Accumulation of butyltin compounds in benthic biota of the Mersey Estuary. Mar Pollut Bull, 50(2): 223-226.

Hawkins, S.J., Gibbs, P.E., Pope, N.D. et al (2002). Recovery of polluted ecosystems: the case for longterm studies. Mar Environ Res 54(3-5):215-222.

Langston, W. J. and Burt, G. R. (1991). Bioavailability and effects of sediment-bound TBT in depositfeeding clams, Scrobicularia plana. Mar Environ Res, 32: 61-77.

Langston, W.J., and Pope, N.D. (1995). Determinants of TBT Adsorption and Desorption in Estuarine Sediments. Mar Pollut Bull 31(1-3):32-43. 
Langston, W.J., Burt, G.R. and Chesman, B.S. (2007). Feminisation of male clams Scrobicularia plana from estuaries in South West UK and its induction by endocrine-disrupting chemicals. Mar. Ecol. Prog. Ser. 333:173-184.

Langston, W.J., Burt, G.R., Zhou, M. (1987). Tin and organotin in water, sediments, and benthic organisms of Poole Harbour. Mar Pollut Bull 18: 634-639.

Langston, W.J., Bryan, G.W., Burt, G.R. and Gibbs, P.E. (1990). Assessing the impact of tin and TBT in estuaries and coastal regions. Funct Ecol 4: 433-443.

Langston, W.J., Bryan, G.W., Burt, G.R. and Pope, N.D. (1994a) Effects of sediment metals on estuarine benthic organisms, R\&D Note 203, National Rivers Authority, 141pp.

Langston, W.J., Bryan, G.W., Burt, G.R. and Pope, N.D. (1994b) Effects of sediment metals on estuarine benthic organisms. Project Record, National Rivers Authority, 49pp.

Maguire, R.J. (2000). Review of the persistence, bioaccumulation and toxicity of tributyltin in aquatic environments in relation to Canada's Toxic Substances Management Policy. Water Qual. Res. J. Canada 35(4): 633-679.

Matthiessen, P. (2008). An assessment of endocrine disruption in mollusks and the potential for developing internationally standardized mollusk life cycle test guidelines. Integrated Environmental Assessment and Management, 4, 274-284.

Matthiessen, P. and Thain, J.E. (1989). A method for studying the impact of polluted marine sediments on intertidal colonising organisms; tests with diesel-based drilling mud and tributyltin antifouling paint. Hydrobiologia, 188/9: 477-485.

Oehlmann, J., Stroben, E. and Fioroni, P. (1991). The morphological expression of Imposex in Nucella lapillus (Linnaeus) (Gastropoda: Muricidae). J Mollusc Stud 57:375-390

OSPAR (2004). OSPAR/ICES Workshop on the evaluation and update of background reference concentrations (B/RCs) and ecotoxicological assessment criteria (EACs) and how these assessment tools 
should be used in assessing contaminants in water, sediment and biota. Hazardous Substances Series, 214. ISBN 1-904426-52-2: 167pp.

OSPAR (2008). Co-ordinated Environmental Monitoring Programme - Assessment manual for contaminants in sediment and biota. Monitoring and Assessment Series, 379/2008. ISBN 978-1-90684020-4: 39pp.

Pope N.D. (1998). The bioavailability of sediment-bound tributyltin (TBT). PhD Thesis, University of Plymouth.

Rato, M., Sousa, M., Quinta, R. et al. (2006). Assessment of inshore/offshore tributyltin pollution gradients in the northwest Portugal continental shelf using Nassarius reticulatus as a bioindicator. Environmental Toxicology and Chemistry 25(12): 3213-3220.

Ruiz, J.M., Barreiro, R., Couceiro, L. and Quintela, M. (2008). Decreased TBT pollution and changing bioaccumulation pattern in gastropods imply butyltin desorption from sediments. Chemosphere, 73: $1253-1257$.

Ruiz, J.M., Bryan, G.W. and Gibbs, P.E. (1994). Bioassaying the toxicity of tributyltin-(TBT)-polluted sediment to spat of the bivalve Scrobicularia plana. Mar Ecol Prog Ser 113: 119-130.

Santos, M.M., Viera, N., Reis-Henriques, M.A., et al. (2004). Imposex and butyltin contaminants off the Oporto Coast (NW Portugal): a possible effect of the discharge of dredged material. Environment International. 30: 793-798.

Side, J. and Jowitt, P. (2002). Technologies and their influence on future UK marine resource development and management. Marine Policy. 26, 231-241.

Smith, R., Bolam, S.G., Rees, H.L. and Mason, C. (2008). Macrofaunal recovery following TBT ban; Longterm recovery of subtidal macrofaunal communities in relation to declining levels of TBT contamination. Environmental Monitoring and Assessment, 136:245-256. 
St-Jean, S.D., Courtenay, S.C., Pelletier, E. and St-Louis, R. (1999). Butyltin concentrations in sediments and blue mussels (Mytilus edulis) of the southern Gulf of St. Lawrence, Canada. Environ. Technol. 20(2): 181-189.

Svavarsson, J., Granmo, A., Ekelund, R. and Szpunars, J. (2001) Occurrence and effects of organotins on adult common whelk (Buccinum undatum) (Mollusca, Gastropoda) in harbours and in a simulated dredging situation. Mar Pollut Bull. 42(5): 370-376.

Ten Hallers-Tjabbes, C.C., Wegener, J-W., Van Hattum, A.G.M. et al. (2003). Organotin levels and imposex development in the benthic gastropods Buccinum undatum, Neptunea antiqua from the North Sea. Relations to shipping density and hydrography. Mar Environ Res 55: 203-233.

Thain, J.E. and Waldock, M.J. (1986). The impact of tributyltin (TBT) antifouling paints on molluscan fisheries. Water, Science and Technology 18: 193-202.

Turner, A. (2010) Marine pollution from antifouling paint particles. Mar. Pollut. Bull. 60 (2): 159-171 Waldock, R., Rees, H.L., Matthiessen, P. et al. (1999) Surveys of the benthic infauna of the Crouch Estuary (UK) in relation to TBT contamination. J Mar Biol Assoc UK 79(2):225-232.

\section{Figure Legends}

Fig. 1. Sampling sites: Poole Harbour (A) and Southampton Water (B). (abbreviations are: Power Stn. = Power Station, Jerry's Pt = Jerry's Point, Up.Itchen = Upper Itchen, M. Hamble = Mid Hamble (Suggested two column width)

Fig. 2. Nucella lapillus sampling sites in SW England: Bude (1), Widemouth (2), Porth Joke (3), St Agnes (4), Castle Drive (5), St Mawes (6), St Anthony Head (7), Devil's Point (8), Plymouth Hoe (9), Batten (10), Renney rocks (11), Saltern Cove (12), Meadfoot (13), Jersey (14). (suggested single column width)

Fig. 3. TBT concentrations ( $\mathrm{ng} \mathrm{L}^{-1}$ as $\mathrm{Sn}$ ) in Poole Harbour waters in relation to EQS : Northern (A) and southern (B) sites - see Fig 1A for locations. (suggested single column width)

Fig. 4. TBT concentrations ( $\mu \mathrm{g} \mathrm{g}^{-1}$ as $\mathrm{Sn}$ ) in Poole Harbour sediments: northern (A) and southern (B) sites (see Fig 1A for locations). Arrows show Cefas Action Levels (AL1 and AL2) for disposal at sea (see text for explanation). (suggested single column width) 
Fig. 5. Scrobicularia plana. TBT concentrations ( $\mu \mathrm{g} \mathrm{g}^{-1}$ as $\mathrm{Sn}$ ) in Poole Harbour: northern (A) and southern (B) sites -see Fig 1A for locations. (suggested single column width)

Fig. 6. TBT concentrations ( $\mathrm{ng} \mathrm{L}^{-1}$ as $\mathrm{Sn}$ ) in Hamble, Itchen and Test Estuary water, Southampton, in relation to EQS. For Hamble and Itchen, regression lines are for all sites; for Test, lines for individual sites (Cracknore and Totton) are plotted separately because of disparity (see Fig 1B for locations). (suggested single column width).

Fig. 7. TBT concentrations ( $\mu \mathrm{g} \mathrm{g}^{-1}$ as $\mathrm{Sn}$ ) in Hamble, Itchen and Test Estuary sediment, Southampton (see Fig 1B for locations). Arrows show Cefas Action Levels (AL1 and AL2) for disposal at sea (see text). (suggested single column width)

Fig. 8. Scrobicularia plana. TBT concentrations ( $\mu \mathrm{g} \mathrm{g}^{-1}$ as $\mathrm{Sn}$ ) in Hamble, Itchen and Test Estuary, Southampton (see Fig 1B for locations). (suggested single column width)

Fig. 9. Scrobicularia plana. Abundance of clams (numbers collected per man hour) at sites in the Hamble Estuary 1978-2009. Data in 1978 are total clam numbers; numbers of different sized clams (10 $\mathrm{mm}$ intervals) are indicated at other times. Upper numbers above bars are mean TBT seawater concentrations (ng L ${ }^{-1}$ as Sn) for periods 1986-1988, 1990-1992, 2000-2009 (left to right). Lower numbers are mean sediment TBT concentrations ( $\mu \mathrm{g} \mathrm{g}^{-1}$ as $\mathrm{Sn}$ ) for the same periods.

(Suggested two- column width)

Fig. 10. Scrobicularia plana. Abundance of clams (numbers collected per man hour) at sites in the Itchen Estuary 1978-2009. Data in 1978 are total clam numbers; numbers of different sized clams (10 $\mathrm{mm}$ intervals) are indicated at other times. Upper numbers above bars are mean TBT seawater concentrations (ng L' ${ }^{-1}$ as Sn) for periods 1986-1988, 1990-1992, 2000-2009 (left to right). Lower numbers are mean sediment TBT concentrations ( $\mu \mathrm{g} \mathrm{g}^{-1}$ as $\mathrm{Sn}$ ) for the same periods.

(Suggested two- column width)

Fig. 11. Scrobicularia plana. Abundance of clams (numbers collected per man hour) at sites in the Test Estuary 1978-2009. Data in 1978 are total clam numbers; numbers of different sized clams (10 mm intervals) are indicated at other times. Upper numbers above bars are mean TBT seawater concentrations (ng L ${ }^{-1}$ as Sn) for periods 1986-1988, 1990-1992, 2000-2009 (left to right). Lower numbers are mean sediment TBT concentrations ( $\mu \mathrm{g} \mathrm{g}^{-1}$ as $\mathrm{Sn}$ ) for the same periods.

(Suggested two- column width)

Fig. 12. Nucella lapillus. Size - frequency abundances, Plymouth Hoe (Site 9, Fig. 2). Filled bars represent individuals with no teeth on the shell margin (usually juveniles or sub-adults); unfilled bars represent individuals with dentate outer lip (usually adults). 1985 sample is from Drake's Island, offshore, due to elimination from the Hoe site. (Note: despite the presence of adults at the Drake's Island site, the absence of juveniles indicates negligible new recruitment). (suggested single column width)

Fig. 13. Nucella lapillus. Changes in mean VDSI at four SW sites over a 25 year period. See Figure 2 for locations. (suggested single column width)

Fig. 14. Scrobicularia plana. Relationship between sex ratio and TBT content of sediment, Poole and Southampton, July 2009. Dashed line is mean ( \pm SE) sex ratio for English Channel (2009-2012, n=107 sites). (suggested single column width) 